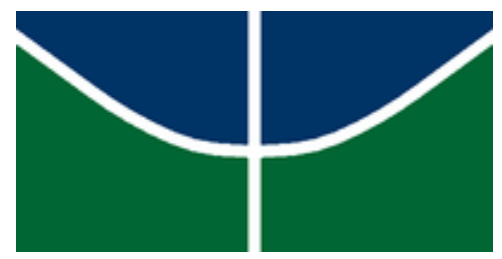

Universidade de Brasília

Instituto de Ciências Biológicas

Programa de Pós-Graduação em Ecologia

ELBA MILITÃO

\title{
PADRÃO DE ATIVIDADE TEMPORAL DE MORCEGOS INSETÍVOROS NO CERRADO
}

BRASÍLIA

2017 


\section{PADRÃO DE ATIVIDADE TEMPORAL DE MORCEGOS INSETÍVOROS NO CERRADO}

\section{Elba Sancho Garcez Militão}

Dissertação apresentada ao Programa de Pós-Graduação em Ecologia da Universidade de Brasília como parte dos requisitos necessários para a obtenção do título de Mestre em Ecologia.

Orientadora: Ludmilla M. S. Aguiar

BRASÍLIA

2017 
Aos meus avós, Vó Ete, Vó Jesus e Vô Raimundo.

Obrigada por me amar e entender minha ausência.

Dedico a vocês. 


\section{AGRADECIMENTOS}

Agradeço primeiramente ao multiverso por colocar todas as melhores pessoas em minha vida! De verdade, se não fosse isso, eu tinha desistido antes do primeiro passo. E falando em primeiro passo, sou obrigada a pedir desculpas aos seres humanos do mundo, que não meus irmãos $(<3)$, porque eu fiquei com os melhores pais, Júlio e Angeliete Militão. Eles além de torcerem por mim em todos os meus jogos sempre me deram apoio para superar todos meus desafios, até mesmo aqueles que eles acham estranhos.

Agradeço também a minha orientadora, amiga, conselheira, tranquilizadora Ludmilla que, por acreditar em mim, mudou a minha vida, abriu minha cabeça e me ensinou tudo! Desde fazer nó em corda a escrever. Obrigada pela sua paixão pelos morcegos. Confesso que é contagiante. E aos colegas de laboratório Thiago, Daniel, Veronica e Renato pelas conversas, discussões e risadas. Aos melhores bat-estagiários do mundo Claysson, Camila, Dani, Débora e Claysson (duas vezes), muito obrigada por sua sanidade e horas de vida ao meu lado no computador. E aos demais companheiros de laboratório por que sério, vocês são sensacionais S2.

Agradeço demais aos meus amores do corredor que fazem a minha vida mais feliz todos os dias. Júlia Borges, obrigada por viver no mesmo planeta que eu! Sério, muito obrigada! Renatinha, obrigada por me passar um pouco desse foco e conhecimento. Pedro Moraes obrigada pelos abraços, carinhos e risadas. Leleco maizilindodomeucoraçao obrigada pelo seu cérebro, e pontos de vista e conversas sobre números. Samia obrigada por sempre dar um jeito de me ajudar em qualquer coisa sempre todas as vezes. Bruna Martins, obrigada por estar na minha vida, por me escutar biologar até quando a gente toma um sorvetinho.

Gratidão por meus amigos de ECO-ZOO, obrigada por serem todos tão ótimos, solícitos, e por compartilharem sofrimentos e alegrias. Meu coração vibra com vocês para sempre. Ensaiei escrever os nomes de todos, mas fiquei com medo de esquecer alguém, então só sintam meu amor. E segura que é muito hein!

Aos meus ótimos professores, seres de luz, que além de passarem o conhecimento, passam também lições de vida. OBRIGADA POR SEREM MEUS EXEMPLOS! Em especial ao Pacheco (vulgo Ricardo Machado), Heloísa Miranda, Mercedes Bustamante, Isabel Schmidt, Tri, Ludgero, Guarino e Maria João (não oficial, mas fundamental). 
Agradeço ao Cnpq pela bolsa e à FAPDF por tornar possível minha ida ao congresso de quirópteros em 2016.

E por último, mas não menos importante aos meu "irmões" de vida. Obrigada por entenderem minha ausência, puxarem minha orelha nas minhas faltas e tornarem nossa distância física quase imperceptível. Amo vocês. 


\section{SUMÁRIO}

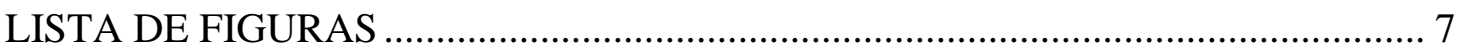

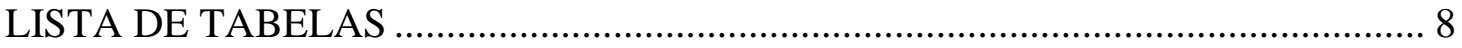

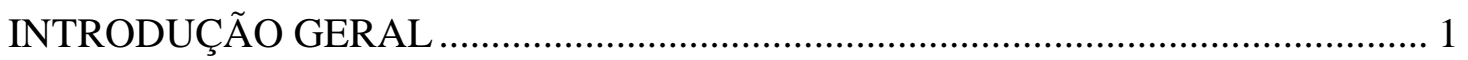

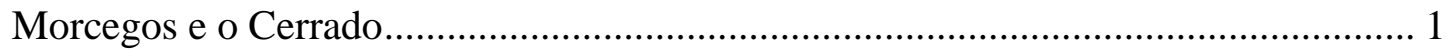

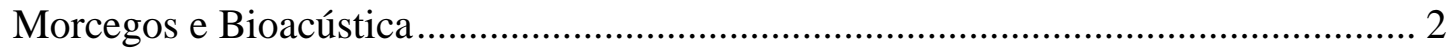

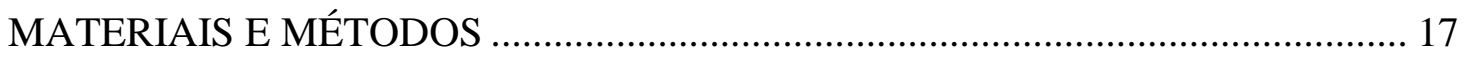

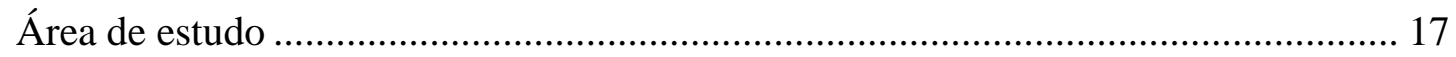

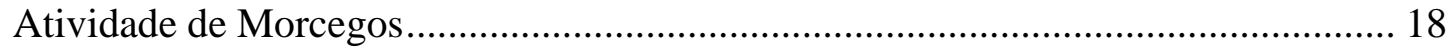

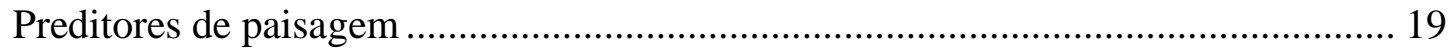

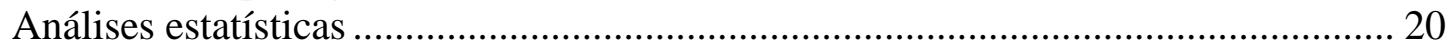

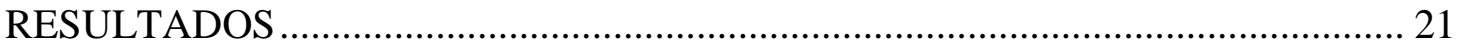

1) Atividade de morcegos insetívoros registradas ao longo da noite no módulo PPBio instalado no Parque Nacional de Brasília................................................................... 21

2) Atividade de morcegos insetívoros entre os pontos amostrais do módulo PPBio instalado no Parque Nacional de Brasília..................................................................... 22

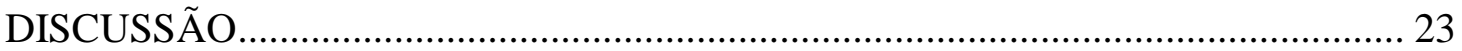

1) Atividade de morcegos insetívoros registradas ao longo da noite das amostragens no módulo instalado no Parque Nacional de Brasília é bimodal ..................................... 23

2) A atividade de morcegos insetívoros é diferente entre cada um dos pontos amostrais do módulo PPBio instalado no Parque Nacional de Brasília...................................... 24

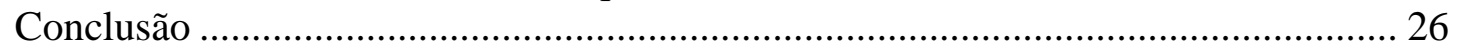

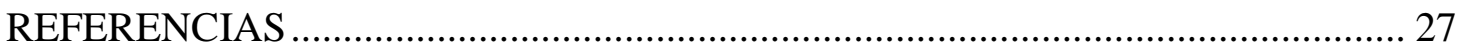




\section{LISTA DE FIGURAS}

Introdução Geral

Figura 1: Representação gráfica do chamado de um Promops centralis da família Molossidae, (espectrograma, oscilograma e power spectrum), e métricas de análise do pulso. Imagem retirada de Jung et al. (2014).

Figura 1: Espectograma do chamado emitido por cada guilda de morcego. Aqui estão representadas todas as fases do chamado de ecolocalização: fase de busca a fase final de aproximação. Destacado em amarelo os forrageadores de ambiente aberto, em verde os forrageadores de ambiente de borda de mata e em vermelho os forrageadores de ambiente fechado (Figura adaptada de Denzinger e Schnitzler, 2013)

\section{CAPÍTUTLO 1. PADRÃO DE ATIVIDADE TEMPORAL DE MORCEGOS INSETÍVOROS NO CERRADO}

Figura 1: Atividade de morcegos registradas ao longo das noites de amostragem, nos meses de agosto e setembro de 2014, nas parcelas do módulo PPBio instalado no Parque Nacional de Brasília

Figura 2: Frequência média $(\mathrm{kHz})$ dos chamados de morcegos detectados automaticamente pelo programa Kaleidoscope PRO em relação às horas após o pôr-dosol nas noites de amostragem, nos meses de agosto e setembro de 2014, nas parcelas do módulo PPBio instalado no Parque Nacional de Brasília.

Figura 3: Padrão de atividade de morcegos insetívoros nas noites de amostragem, nos meses de agosto e setembro de 2014, nas parcelas do módulo PPBio instalado no Parque Nacional de Brasília.nos pontos do módulo PPBio instalado no Parque Nacional de Brasília. Os eixos Y é diferente entre os gráficos 365

Figura 4: Número de espécies identificadas em cada grupo funcional nas parcelas do módulo PPBio instalado no Parque Nacional de Brasília 356 


\section{LISTA DE TABELAS}

Tabela 1: Espécies e número de passes identificados automaticamente pelo programa Kaleidoscope PRO nas parcelas do módulo PPBio instalado no Parque Nacional de Brasília. FAA: forrageador de área aberta; FAB: forrageador de área de borda. 38

Tabela 2: Modelo selecionado que melhor explica a atividade de morcegos insetívoros no módulo PPBio instalado no Parque Nacional de Brasília. NDVI = índice de vegetação por diferença normalizada; dist.agua $=$ distância do corpo d'água mais próximo; Div.450 = índice de diversidade de Simpson (1-D) da paisagem, calculado por um buffer de 450 metros.

Tabela 3: Métricas de paisagem no módulo PPBio instalado no Parque Nacional de Brasília. NDVI = índice de vegetação por diferença normalizada; Diversidade = índice de diversidade de Simpson (1-D). 40 


\section{INTRODUÇÃO GERAL}

\section{Morcegos e o Cerrado}

O Cerrado é a savana mais diversa do mundo (Klink e Machado, 2005), e os morcegos são os mamíferos que mais influenciam a riqueza e diversidade desta região (Paglia et al., 2012). O bioma é considerado uma das últimas fronteiras de agricultura do mundo (Borlaug, 2002) e vem sofrendo significativas mudanças em seu formato original. Pelo menos $67 \%$ da área natural do Cerrado já foi convertida para uso humano (Cavalcanti e Joly, 2002) e estima-se que $80 \%$ do bioma já sofreu alguma interferência antrópica (Myers et al., 2000). O que agrava a situação é o fato de que cerca de 4\% da área total do bioma ser legalmente protegida em áreas de proteção integral e de uso sustentável (Klink e Machado, 2005). Inclusive, existem estimativas de que 20\% das espécies endêmicas do Cerrado não são protegidas por estas áreas (Machado et al., 2004).

O Cerrado é constituído por um mosaico de formações vegetais que variam desde campos até formações densas de florestas (cerradão e matas de galeria) (Ribeiro e Walter, 2008). Apresenta heterogeneidade marcadamente distribuída no eixo horizontal onde é possível observar grandes mudanças na fitofisionomia em pouca distância. Ocupa uma área de aproximadamente 1,8 milhão de $\mathrm{km}^{2}$ (cerca de $21 \%$ do território brasileiro), e mais de $40 \%$ dos mamíferos registrados para o domínio são espécies de morcegos, o grupo de mamíferos mais diversificado do bioma (Aguiar et al., 2016). No entanto a perda anual de áreas nativas tem sido muito acentuada, calcula-se 2,2 milhões de hectares (Machado et al., 2004). Segundo Bernard et al. (2011) apenas 6\% do bioma é minimamente amostrado para morcegos indicando a urgência na conservação destes animais.

Hoje estima-se que mais de 118 espécies de morcegos existam no Cerrado (Aguiar et al., 2016). Uma característica importante deste grupo é a ampla gama de hábitos alimentares. Os morcegos formam o único grupo de mamíferos que apresentam todos os hábitos alimentares, com representantes hematófagos frugívoros, nectarívoros, carnívoros, piscívoros e insetívoros, sendo, portanto, realizadores de diversos serviços ecossistêmicos, tais como polinização, dispersão e controle de pragas agrícolas (Kunz et al., 2011). A literatura demonstra que os insetívoros são importantes bioindicadores de equilíbrio de um ecossistema (Cunto e Bernard, 2012), pois, alimentam-se de insetos de 
interesse econômico (pestes agrícolas) e, por apresentarem um ciclo de vida longo, estes morcegos podem acumular agrotóxicos e outros tipos de toxinas em seus tecidos indicando a saúde do ecossistema (Jones et al., 2009).

Diversos temas já foram abordados em estudos de morcegos no Cerrado, tais como a dieta (Aguiar e Antonini, 2008), reprodução (Zortéa, 2003), resposta à fragmentação (Loureiro e Gregorin, 2015; Muylaert et al., 2016), competição (Willig et al., 1993; Amaral et al., 2016). Os Phyllostomidae são ditos como os morcegos mais abundantes do Cerrado (Teixeira et al., 2015; Muylaert et al., 2016; Olímpio et al., 2016). Esta afirmação está baseada em trabalhos realizados com redes de neblina, método amplamente utilizada no estudo de quirópteros. A rede pretende interceptar os animais durante o voo e normalmente é armada na altura do sub-bosque, selecionando morcegos que forrageiam neste estrato.

Os índices de captura de morcegos insetívoros em redes de neblina são muito baixos, pois, devido ao acurado sistema de ecolocalização, estes animais conseguem perceber onde a rede está e voar acima dela (Kalko et al., 1996). Esses animais são sub amostrados por trabalhos realizados com rede neblina (Bernard et al., 2011). Os trabalhos que amostram alguma espécie insetívora contam com a captura de poucos indivíduos (Willig et al., 1993; Aguiar e Antonini, 2008). Por isso, métodos envolvendo a bioacústica são considerados ferramentas mais apropriadas para estudos envolvendo atividade de morcegos insetívoros (Meyer et al., 2004).

\section{Morcegos e Bioacústica}

A bioacústica é a ciência que estuda o som emitido por seres vivos. Trata-se de uma ferramenta poderosa para documentar a biodiversidade. Grupos de animais produzem vocalizações para diversos fins, tais como demarcação de território, encontrar um par para a cópula e até mesmo se orientar e encontrar alimento.

O sofisticado sistema de detecção de objetos através do uso do som é chamado de ecolocalização. Este sistema se baseia no cálculo diferencial da emissão de um sinal sonoro, normalmente de alta frequência, e o retorno do reflexo do objeto detectado (eco) e já foi documentado em algumas espécies de aves (Apodiformes e Caprimulgiformes) e mamíferos (Afrosoricida, Eulipotyphla, Chiroptera e Cetacea) (Thomas et al., 2002), 
sendo os dois últimos os únicos a utilizarem este sistema para localizar e capturar alimentos.

Morcegos emitem sinais de alta frequência através da laringe, com exceção de Rousettus spp., que o faz através de cliques produzidos pela língua (Fenton, 2013). Este comportamento é extremamente complexo e sofisticado. O pulso de ecolocalização permite uma avaliação do comportamento e da ecologia dos morcegos. Esses animais podem separar o pulso emitido do eco recebido pelo tempo ou pela frequência (Fenton, 2013). Os que separam pelo tempo são chamados de low duty cycle, eles emitem sinais curtos separados por um longo período de silêncio. Em contraposição, os que separam o pulso emitido do eco recebido pela frequência são chamados de high duty cycle e produzem chamados longos separados por curtos períodos de silêncio. O conjunto de pulsos, com seus respectivos intervalos formam um passe de morcego, que significa um rastro da passagem do animal pelo espaço (Fenton, 2013). Devido a estas diferentes estratégias de emissão de pulsos é importante considerar qual destas estratégias o animal utiliza ao se contabilizarem os passes de morcegos, uma vez que o tamanho do passe variará, também, de acordo com o período de silêncio emitido pelo animal.

O pulso de ecolocalização (figura 1) é caracterizado pela (i) duração do pulso e o intervalo entre dois pulsos consecutivos, medidos em milissegundos, (ii) frequência, máxima e mínima que o pulso alcança medida em kilohertz $(\mathrm{kHz})$ registrada no pico de maior intensidade do pulso, e a largura de banda, por meio da diferença entre a frequência máxima e a mínima, e sua (iii) intensidade, medida em decibéis (db) (Mora e Macías, 2007). A estrutura do chamado, reflete relações filogenéticas, uma vez que espécies classificadas na mesma família taxonômica apresentam pulsos de ecolocalização com estrutura semelhante (Jung et al., 2014). 


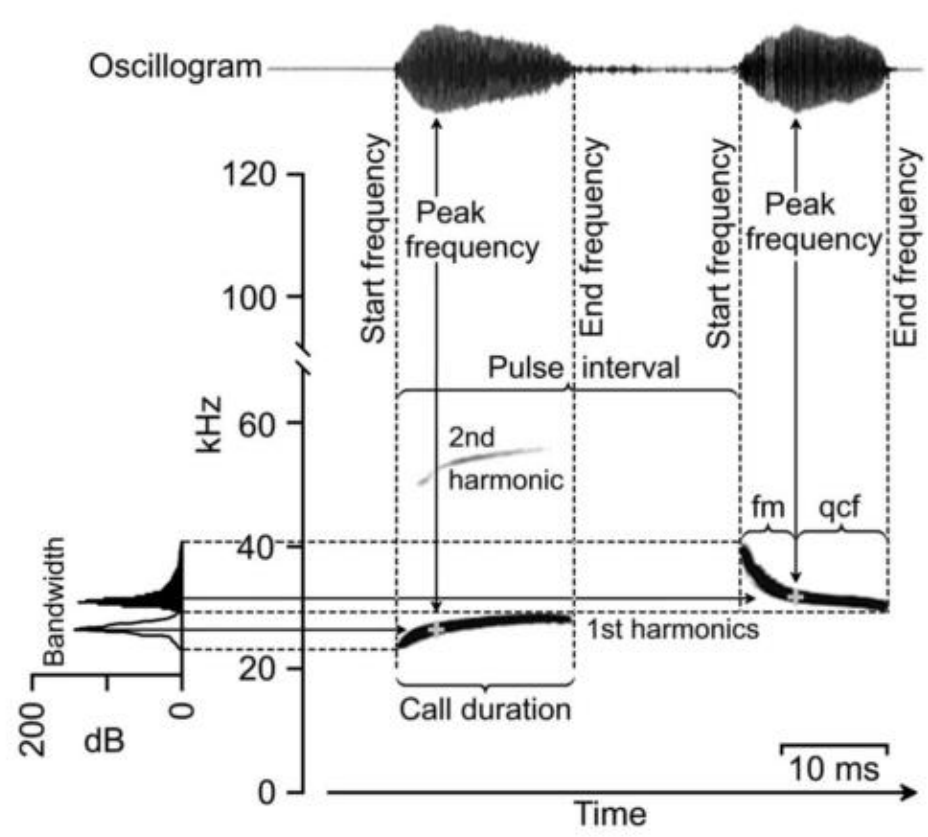

Figura 1: Representação gráfica do chamado de um Promops centralis da família Molossidae, (espectrograma, oscilograma e power spectrum), e métricas de análise do pulso. Imagem retirada de Jung et al. (2014).

Para explorar recursos representados por insetos noturnos, morcegos devem emitir sons de alta frequência, que produzem um eco mais forte de pequenos alvos. Para produzir sons em alta frequência eles devem ser pequenos. Por tanto é possível agrupar os morcegos baseadas em chamados de ecolocalização. Schnitzler e Kalko (2001) e Denzinger e Schnitzler (2013) agruparam estes animais em grupos funcionais de acordo com os seguintes locais de forrageio (figura 2):

(i) Forrageadores de ambiente aberto

Animais que forrageiam nesta condição precisam detectar a presa a uma longa distância, sem se preocupar com o eco de fundo produzido pelo ambiente. Portanto, o pulso de ecolocalização é longo ( 8 - 25ms) de banda estreia e uma ligeira modulação (Denzinger e Schnitzler, 2013). Esse formato de pulso amplia o eco do inseto detectado e aumenta a probabilidade de captura (Schnitzler e Kalko, 2001). A frequência do chamado é geralmente inferior a $30 \mathrm{kHz}$ e com intervalo entre os pulsos longo. Suas asas são adaptadas para voo rápido e com baixo custo energético.

(ii) Forrageadores de ambiente de borda 
Animais que forrageiam nestas condições necessitam distinguir o eco da presa e o do ambiente de fundo (Schnitzler e Kalko, 2001). Portanto, emitem pulsos mistos apresentando sinais de banda estreita e levemente modulada, e um componente de banda larga e frequência modulada descendente (Denzinger e Schnitzler, 2013). O sinal apresenta frequência que varia entre 30 e $60 \mathrm{kHz}$. O padrão de asas varia, havendo espécies que voam rápido e algumas mais lentas, com asas grandes e largas para maior manobrabilidade. A presença do uropatágio auxilia nesta função.

(iii) Forrageadores de ambiente fechado

A presa destes animais está confundida com o ambiente, portanto esses animais lançam mão de três estratégias: (a) detectam o ritmo das asas da presa, (b) utilizam outros sentidos, que não a ecolocalização, para detecção da presa, são catadores passivos, e (c) os catadores ativos, que utilizam a ecolocalização para encontrar alimentos conspícuos como flores e frutos (Schnitzler e Kalko, 2001). Os sinais de ecolocalização apresentam frequência modulada e alta $(60 \mathrm{kHz})$ e duração entre 15 e 35ms (Denzinger e Schnitzler, 2013). Normalmente possuem asas curtas e largas para auxiliar na locomoção em ambiente fechado.

Com o barateamento dos equipamentos de aparelhos para gravação de sons com alta frequência, em países em desenvolvimento, onde está concentrada a maior biodiversidade, tornou-se possível monitorar a atividade de morcegos insetívoros com maior confiabilidade (Meyer et al., 2004). Willig et al. (1993), inclusive, discutem que o maior obstáculo ao progresso na compreensão da ecologia das comunidades de morcegos é o pouco conhecimento que temos sobre auto-ecologia das espécies.

Na região neotropical o uso da bioacústica para monitoramento de morcegos é relativamente recente, se comparado com o da região temperada, em parte, pelo fato de na região temperada só existirem morcegos insetívoros e, por outro lado, o alto custo dos equipamentos de gravação (MacSwiney et al., 2008). Os trabalhos com esta técnica focaram inicialmente na descrição de chamados (Rydell et al., 2002; Jung et al., 2007; Mora e Macías, 2007), e só posteriormente os padrões de atividade e sua relação com a paisagem. Porém estes trabalhos estão concentrados em áreas de floresta tropicais, principalmente no Panamá (Lang et al., 2006; Jung e Kalko, 2011; Estrada-Villegas et al., 2012; Bader et al., 2015) 


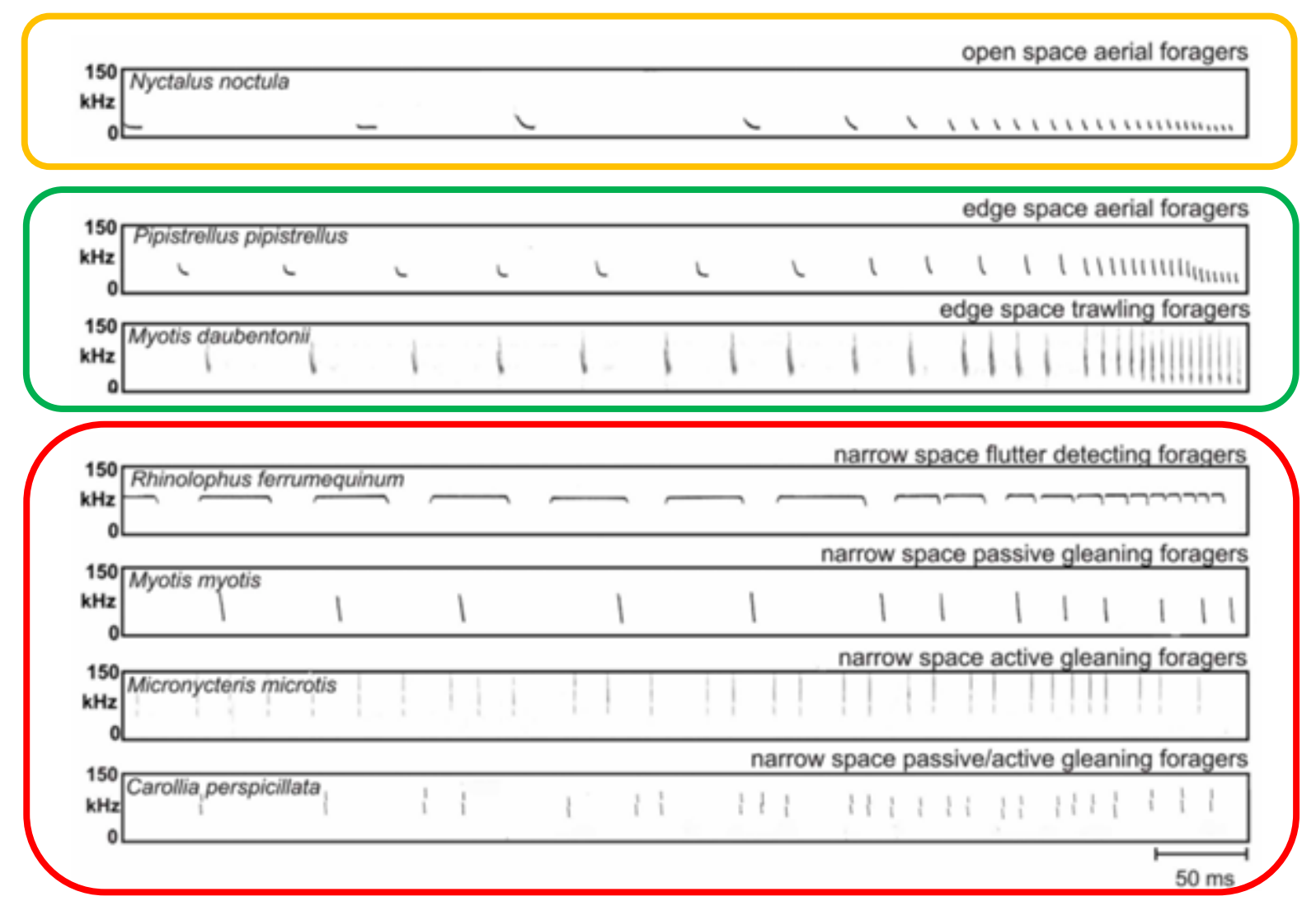

Figura 2: Espectograma do chamado emitido por cada guilda de morcego. Aqui estão representadas todas as fases do chamado de ecolocalização: fase de busca e fase final de aproximação. Destacado em amarelo os forrageadores de ambiente aberto, em verde os forrageadores de ambiente de borda de mata e em vermelho os forrageadores de ambiente fechado (Figura adaptada de Denzinger e Schnitzler, 2013)

\section{Atividade de morcegos}

Os padrões de atividade temporal indicam como as espécies exploram o ambiente e geralmente são considerados como reflexo da repartição de nicho (Pianka, 1973). Mudanças no uso da terra podem alterar o padrão temporal de como as espécies exploram os recursos do ambiente (Presley et al., 2009a). Entender esse padrão é importante para a previsão de acontecimentos futuros das espécies.

Para a conservação e mitigação de impactos sobre as comunidades biológicas é necessário compreender como as populações interagem e ocupam os espaços do nicho, uma vez que a partição temporal de nicho possibilita a coexistência de animais que utilizam o mesmo recurso alimentar (Carothers e Jaksić, 1984).

Trabalhos sobre a variação temporal diária de morcegos durante a noite indicam que existe um grande pico de atividade após o pôr-do-sol, devido à competição por fruto 
ou néctar (Marinho-Filho e Sazima, 1989; Pedro e Taddei, 2002; Aguiar e Marinho-Filho, 2004; Presley, et al., 2009a; Presley et al., 2009b). No caso destes recursos fica clara a necessidade de consumir o fruto ou o néctar primeiro. Uma vez que, se o animal demorar, um competidor em potencial poderá consumir antes. Diferente do fruto e do néctar o recurso dos morcegos insetívoros é facilmente reposto durante a noite.

A atividade temporal de morcegos insetívoros já foi estudada em regiões temperadas (Kunz, 1973; Hayes, 1997; Broders et al., 2003) e em algumas savanas africanas (Fenton e Thomas, 1980; Meyer et al., 2004; Taylor et al., 2013). Este padrão pode variar dependendo da espécie (Kunz, 1973). Porém, mesmo em diferentes regiões, no geral, há um padrão na atividade dos insetívoros, que apresentam um pico de atividade no início da noite, uma queda no decorrer da noite, e um segundo pico de atividade pouco antes do amanhecer (Taylor e O’Neill, 1988; Hayes, 1997; Meyer et al., 2004). A diferenciação de horários de forrageio é justificada para morcegos insetívoros uma vez que o recurso alimentar é facilmente renovado durante a noite, como discutido por Aguiar e Marinho-Filho (2004) e Marinho-Filho e Sazima (1989).

Assim, a proposta desta dissertação é contribuir para o avanço do conhecimento sobre o padrão de atividade temporal de morcegos insetívoros na savana neotropical e relacionar esta atividade ao contexto da paisagem. Nesse estudo o número de passes de ecolocalização em fase de busca foi contabilizado. Foi considerado um passe sempre que três ou mais pulsos em fase de busca estavam presentes. Um passe foi separado do outro sempre que a distância entre os pulsos fosse superior a três vezes o intervalo entre os pulsos. Foi utilizado o software automático Kaleidoscope Pro versão 3.1.8 (Wildlife Acoustics) para a identificação dos chamados. O capítulo da dissertação está formatado como artigo científico que será submetido para a Acta Chiropterologica. As figuras e tabelas foram adicionadas no final das referências bibliográficas. 


\section{REFERENNCIAS}

Aguiar, L. M. S. and Y. Antonini,. 2008. Diet of two sympatric insectivores bats (Chiroptera: Vespertilionidae) in the Cerrado of Central Brazil. Revista Brasileira de Zoologia, 25(1): 28-31.

Aguiar LMS, Bernard E, Machado RB, Jones G. 2016. Should I stay or should I go? Climate change effects on the future. Glob Ecol Conserv. 5: 22-33.

Aguiar, L M. S., R. Machado and J. Marinho-Filho. 2004. The biological divirsiy in Cerrado. Pp. 19 - 42, in Cerrado: ecology and characterization (L. M. S. Aguiar and A. J. Camargo eds). Planaltina: Embrapa-CPAC. [In Portuguese]

Aguiar, L.M.S. and J. Marinho-Filho, 2004. Activity patterns of nine phyllostomid bat species in a fragment of the Atlantic Forest in southeastern Brazil. Revista Brasileira de Zoologia, 21(2): 385-390.

Almeida, M.H., A. D. Ditchifield and R. S. Tokumaru. 2007. Bats activity and habitat preference in the urban area of Grande Vitória, ES, Brazil.Zoociências, 9(1): 13-18.

Amaral, T.S., L. M. Macário and L. M. S. Aguiar. 2016. Testing the Coexistence of Artibeus lituratus and A. planirostris in a Neotropical Savanna. Acta Chiropterologica, 18(2): 441-449.

Bader, E., K. Jung, E. K. V. Kalko, R. A. Page, R. Rodriguez and T. Sattler. 2015. Mobility explains the response of aerial insectivorous bats to anthropogenic habitat change in the Neotropics. Biological Conservation, 186: 97-106.

Bernard, E., L. M. S. Aguiar and R. B. Machado, R.B. 2011. Discovering the Brazilian bat fauna: A task for two centuries? Mammal Review, 41(1):23-39.

Borlaug, N.E. 2002. Feeding a World Of 10 Billion People: The Miracle Ahead. Pp. 29 59, in Global warming and other eco-myths (R. Bailey, ed). Roseville, California: Competitive Enterprise Institute, 1-320

Broders, H.G., G. M. Quinn and G. J. Forbes. 2003. Species Status, and the Spatial and Temporal Patterns of Activity of Bats in Southwest Nova Scotia, Canada. 
Northeastern Naturalist, 10(4): 383-398.

Carothers, J.H. and F. M. Jaksić. 1984. Time as a Niche Difference: The Role of Interference Competition. Oikos, 42(3): 403-406.

Cavalcanti, R. B. and C. A. Joly, C.A. 2002. Biodiversity and Conservation Priorities in the Cerrado Region. Pp351-368,. in The Cerrados of Brazil: Ecology and Natural History of a Neotropical Savanna. (P. S. Oliveira and R. J. Marquis, eds.) New York: Columbia University Press, 398 pp.

Cunto, G. C. and E. Bernard, E. 2012. Neotropical Bats as Indicators of Environmental Disturbance: What is the Emerging Message? Acta Chiropterologica, 14(1): 143151.

Denzinger, A. and H. U. Schnitzler., 2013. Bat guilds, a concept to classify the highly diverse foraging and echolocation behaviors of microchiropteran bats. Frontiers in Physiology, 4: 1-16.

Estrada-Villegas, S., B. J. Mcgill and E. K. V. Kalko. 2012. Climate, habitat, and species interactions at different scales determine the structure of a Neotropical bat community. Ecology, 93(5): 1183-1193.

Fenton, B. 2013. Evolution of Echolocation. Pp. 47-70, in Bat Evolution, Ecology, and Conservation (R. A. Adams and S. C. Pedersen, eds.). New York: Springer, 547 p.

Fenton, M.B. and D. W. Thomas. 1980. Dry-season overlap in activity patterns, habitat use, and prey selection by sympatric African insectivorous bats. Biotropica, 12(2):81-90.

Hayes, J.P., 1997. Temporal variation in activity of bats and the design of echolocationmonitoring studies. American Society of Mammalogists, 78(2): 514-524.

Jones, G., D. S. Jacobs, T. H. Kunz, M. R. Wilig, P. A Racey. 2009. Carpe noctem: The importance of bats as bioindicators. Endangered Species Research, 8(1-2): 93-115.

Jung, K. and E. K. V. Kalko. 2011. Adaptability and vulnerability of high flying Neotropical aerial insectivorous bats to urbanization. Diversity and Distributions, 
17(2): 262-274.

Jung, K., E. K. V. Kalko and O. Von-Helversen. 2007. Echolocation calls in Central American emballonurid bats: Signal design and call frequency alternation. Journal of Zoology, 272(2): 125-137.

Jung, K., J. Molinari and E. K. V. Kalko. 2014. Driving factors for the evolution of species-specific echolocation call design in new world free-tailed bats (Molossidae). PLoS ONE, 9(1).

Kalko, E. K. V., C. O. Handley and D. Handley. 1996. Organization, Diversity, and LongTerm Dynamics of a Neotropical Bat Community. Pp. 503-553, in: Long-Term Studies of Vertebrate Communities. (M. L. Cody and J. A. Smallwood, eds). Academic Press, 597 p.

Klink, C. A. and R. B. Machado. 2005. Conservation of the Brazilian Cerrado. Conservation Biology, 19(3): 707-713.

Kunz, T. H. 1973. Resource utilization: temporal and spatial components of bat activity in central Iowa. Journal of Mammalogy, 54(1): 14-32.

Kunz, T. H., E. B. Torrez, D. Bauer, T. Lobova, T. H. Fleming. 2011. Ecosystem services provided by bats. Annals of the New York Academy of Sciences, 1223(1): 1-38.

Lang, A. B., E. K. V. Kalko, H. Römer, C. Bockholdt, D. K. N. Dechmann. 2006. Activity levels of bats and katydids in relation to the lunar cycle. Oecologia, 146(4): 659666.

Loureiro, L.O. and R. Gregorin. 2015. Structure of a bat assemblage from a fragmented landscape in the state of Minas Gerais, Southeastern Brazil. Mastozoología Neotropical, 22(1): 35-42.

Machado, R. B., M. B. Ramos-Neto, M. B. Harris, R. Lourival, L. M. S. Aguiar. 2004. Analysis of gaps in biodiversity protection in the Cerrado, in: Anais do IV Congresso Brasileiro de Unidades de Conservação. Vol II:29-38. [In Portuguese] 
MacSwiney G, M. C., F. M. Clarke and P. A. Racey. 2008. What you see is not what you get: The role of ultrasonic detectors in increasing inventory completeness in Neotropical bat assemblages. Journal of Applied Ecology, 45(5): 1364-1371.

Marinho-Filho, J. and I. Sazima. 1989. Activity patterns of six phyllostomid bat species in Southeastern Brazil. Revista Brasileira de Biologia, 49: 777-782.

Meyer, C.F.J., Schwarz, C.J. and Fahr, J., 2004. Activity patterns and habitat preferences of insectivorous bats in a West African forest-savanna mosaic. Journal of Tropical Ecology, 20 (July), pp. 397-407.

Mora, E.C. and S. Macías. 2007. Echolocation calls of Poey's flower bat (Phyllonycteris poeyi) unlike those of other phyllostomids. Naturwissenschaften, 94(5): 380-383.

Muylaert, R. L., R. D. Stevens and M. C. Ribeiro. 2016. Threshold effect of habitat loss on bat richness in cerrado-forest landscapes. Ecological Applications, 26(6): 18541867.

Myers, N., R. A. Mittermeier, C. G. Mittermeier, G. A. B. Fonseca, J. Kent. 2000. Biodiversity hotspots for conservation priorities. Nature, 403(6772): 853-858.

Olímpio, A. P. P. M. C. S. Ventura, M. J. O. Mascarenhas, D. C. Nascimento, F. A. G. Andrade, E. C. Fraga, M. C. Barros. 2016. Bat fauna of the Cerrado savanna of eastern Maranhão, Brazil, with new species occurrences. Biota Neotropica, 16(3): e20150089.

Paglia, A. P., G. B. Fonseca, A. B. Rylands, G. Herrmann, L. M. S, Aguiar, A. G. Chiarello, Y. Leite, L. P. Costa, S. Siciliano, M. C. M. Kierulff, S. L. Mendes, V. C. Tavares, R. A. Mittermeier, J. L. Patton. 2012. Lista Anotada dos Mamíferos do Brasil / Annotated Checklist of Brazilian Mammals. 2a Edição / 2nd Edition. Occasional Papers in Conservation Biology, No. 6. Conservation International, Arlington, VA. 76pp. 1-76. [In Portuguese].

Pedro, W. A. and V. A. Taddei. 2002. Temporal distribution of five bat species (Chiroptera, Phyllostomidae) from Panga Reserve, south-eastern Brazil. Revista Brasileira de Zoologia, 19(3): 951-954. 
Pianka, E.R., 1973. The structure of lizard communities. Annu. Rev. Ecol. Syst., 4: 5374.

Presley, S. J., M. R. Willig, I. Castro-Arellano and S. C. Weaver (a). 2009. Effects of habitat conservation on temporal activity patterns of Phyllostomid bats in lowland Amozonian rain forest. Journal of Mammalogy, 90(1): 210-221.

Presley, S. J., M. R. Willig, L. N. Saldanha, J. M. Wunderle and I. Castro-Arellano. (b) 2009. Reduced-impact logging has little effect on temporal activity of frugivorous bats (Chiroptera) in lowland amazonia. Biotropica, 41(3): 369-378.

Ribeiro, J. F. and B. M. T. Walter. 2008. The main phytophysiognomies of the Cerrado Biome. Pp 151-212, in Cerrado: ecology and flora vol 1 (S.M. Sano, S.P. Almeida \& J.F. Ribeiro, eds.). Embrapa Cerrados, Planaltina. Ribeiro, J.F. and Walter, B.M.T.,1279 p. [In Portuguese].

Rydell, J., A. Entwistle, P. A. Racey. 2002. Acoustic identification of insectivorous bats (order Chiroptera) of Yucatan, Mexico. Journal of Zoology, 257(1): 27-36.

Rydell, J., A. Entwistle and P.A. Racey. 1996. Timing of Foraging Flights of Three Species of Bats in Relation to Insect Activity and Predation Risk. Oikos, 76(2): 243.

Schnitzler, H. U. and E. K. V. Kalko. 2001. Echolocation by Insect-Eating Bats. BioScience, 51(7): 557.

Taylor, P. J., A. Monadjem and S. J. Nicolaas. 2013. Seasonal patterns of habitat use by insectivorous bats in a subtropical. African Journal of Ecology, 51(4): 552-561.

Taylor, R.J. and M. G. O’Neill. 1988. Summer activity patterns of insectivourous Bats and thier prey in tasmania. Australien Wilflife Research, 55(15): 533-539.

Teixeira, T.S.M., D. Dias and M. M. Vale. 2015. New records and a taxonomic review prompts reassessment of Lonchophylla bokermanni, a rare bat endemic to the Brazilian Cerrado. Oryx, 49(1): 71-73.

Thomas, J.A., C. F. Mossand M. Vater. 2002. Echolocation in bats e dolphins, University of Chicago Press. 631 p. 
Willig, M.R., G. R. Camilo and S. J. Noble. 1993. Dietary overlap in frugivorous and insectivorous bats from edaphic cerrado habitats of Brazil. Journal of Mammalogy, 74(1): 117-128.

Zortéa, M., 2003. Reproductive patterns and feeding habits of three nectarivorous bats (Phyllostomidae: Glossophaginae) from the Brazilian Cerrado. Brazilian Journal of Biology, 63(1): 159-168. 


\title{
PADRÃO DE ATIVIDADE TEMPORAL DE MORCEGOS INSETÍVOROS NO CERRADO
}

\begin{abstract}
6 Cerrado is the most diverse savannah in the world and bats are the mammals that most influence the richness and diversity in this biome. One of the significant problems in

8 studying insectivorous bats in Neotropical region is the low sampling due to the extensive use of mist nets to capture them. To know the activity of insectivore bats

10 during the night and how the landscape influences their habitat choices is fundamental to improve their management. The objective of this work is to evaluate the activity of

12 insectivorous bats along the night and to verify which environmental characteristics (the distance of a body of water, temperature, an amount of biomass and landscape diversity)

14 influence their activity. To do so, I used Song Meter SM2BAT + recorders to record insectivorous bats, installed in ten sampling points at the Brasilia National Park. Bat

16 echolocation passes per hour were recorded, making a total of 242 hours of recording, which resulted in the detection of 5024 passes. Due to the excess of zeros in the

18 samples, the data sets were adapted to a mixed negative binomial model (package R, glmmADMB), having as response variable the number of passes and as the predictive

20 variable the number of hours after the sunset. The pattern of activity is different among points, but bats are active during all night long, showing two peaks of activities, being

22 the first peak just after sunset most intense, and later a more discreet one. When separated into functional groups, the smaller bats used the first half of the night and the

24 larger ones, the second. The numbers of passes were better explained by the distance to the nearest body of water and biomass volume. This relation was positive for the two

26 parameters. Through the observation of the data, I noticed that the landscape context is important for the choice of bat's activity site. The proximity of the forest diminishes the

28 activity of insectivorous bats that prefer to forage in the Cerrado stricto sensu with greater biomass.
\end{abstract}

30 Key words: Neotropical, Bioacoustics, Chiroptera, Savanna, Biomass, Water, functional groups 
Os morcegos são importantes bioindicadores da saúde do ecossistema (Jones et

34 al., 2009). Devido à ampla gama de hábitos alimentares como hematofagia, frugivoria, nectarivoria, carnivoria, piscivoria e insetivoria, estão muito entrelaçados na teia

36 ecológica. Prestam diversos serviços ecossistêmicos que vão desde polinização e dispersão ao controle de pragas agrícolas (Kunz et al., 2011). No entanto a maior parte do conhecimento sobre autoecologia de morcegos é de espécies frugívoras, nectarívoras e hematófagas da família Phyllostomidae (Aguiar e Marinho-Filho, 2004; Bernard, 2002; Presley et al., 2009a; Ramirez-Pulido e Armella, 1987). Esse claro viés ocorre por que morcegos insetívoros são geralmente pouco representados em estudos em toda a região Neotropical, incluindo o Brasil. O método mais utilizado para capturar estes animais é o emprego de redes de neblina que é falho para amostrar morcegos insetívoros uma vez que eles voam em alturas acima do alcance das redes (Kalko et al., 1996). Portanto, informações relacionadas à distribuição local, padrões locais de atividade, assim como associações com o micro-hábitat de muitas espécies de morcegos insetívoros são desconhecidas (Jung e Kalko, 2011).

Um recente aumento no interesse em estudar as relações de hábitat desses morcegos veio acompanhando as melhorias tecnológicas nos equipamentos utilizados para estudo de insetívoros por meio da gravação da vocalização desses animais. Esse avanço tecnológico trouxe também o barateamento dos gravadores e programas para análises (Griffin, 2002). A facilidade na obtenção e no uso de detectores de morcegos é promissora para a compreensão do uso do tempo por morcegos insetívoros. Os padrões de atividade temporal indicam como as espécies exploram o ambiente e geralmente é considerado como reflexo da repartição de nicho (Pianka, 1973).

Hoje o que se conhece sobre o padrão de atividade noturna de morcegos insetívoros teve origem predominantemente dos estudos que foram realizados em localidades na zona temperada do globo. Esses trabalhos indicam um maior pico de atividade inicial nas primeiras horas após o escurecer, seguido de um decréscimo da

60 atividade ao longo da noite, e com um pico menor ao final da noite (Arbuthnott e Brigham, 2007; Broders et al., 2003; Grindal et al., 1999). É interessante observar que independentemente do local de estudo, este mesmo padrão também foi observado para 
morcegos insetívoros em savanas africanas (Meyer et al., 2004; Taylor et al., 2013) e savana subtropical (Hayes, 1997). No entanto, para a região neotropical os registros na literatura sobre a variação noturna na atividade de morcegos são principalmente avaliados em áreas de florestas (Brown, 1968, Jung e Kalko, 2011) e não existem estudos similares para as áreas de cerrado (savana).

No Brasil, o Cerrado é a área onde ocorre maior produção de grãos, e é considerado como uma das últimas fronteiras agrícolas do mundo (Borlaug, 2002). A forte pressão antrópica sobre este bioma já devastou mais de $60 \%$ da sua área nativa (Cavalcanti e Joly, 2002) e junto com seu alto grau de endemismo o caracteriza como um dos 'hotspots' para a conservação da biodiversidade mundial (Myers et al, 2000). O Cerrado possui a mais rica flora dentre as savanas do mundo (Forzza et al., 2012), com alto nível de endemismo, distribuída em uma grande heterogeneidade ambiental expressa na forma de diferentes fitofisionomias que variam desde campos, sem nenhuma árvore ou arbusto (Campo Limpo), até áreas florestais relativamente densas (Cerradão e matas de Galeria), mas com o predomínio das formações savânicas (Ribeiro e Walter, 2008), formando um ambiente naturalmente fragmentado. Esta heterogeneidade é marcadamente distribuída no eixo horizontal, sendo possível observar grandes mudanças na fitofisionomia em poucas distâncias. A riqueza da fauna é igualmente grande, e os morcegos são um importante componente (Aguiar e Zortéa,

82 2008; Paglia et al., 2012).

Os morcegos formam o grupo de mamíferos mais diverso do bioma, onde ocorrem sete das nove famílias de morcegos do Brasil, sendo elas Emballonuridae, Furipteridae, Mormoopidae, Phyllostomidae, Noctilionidae, Vespertilionidae e Molossidae (Aguiar e Zortéa, 2008; Paglia et al., 2012). Exceto Phyllostomidae e Noctilionidae, todas são constituídas por morcegos exclusivamente insetívoros (Erkert, 2000). Estes animais possuem um alto potencial de cobrir grandes distâncias em uma mesma noite (Drescher, 2004), e atravessam facilmente diferentes tipos de vegetação e paisagens que podem constituir uma barreira física para outras espécies de pequenos mamíferos (Bernard and Fenton, 2003). Sabe-se que morcegos respondem à configuração da paisagem, como a proximidade de fontes de água (Brooks e Ford, 2005); Menzel et al., 2005), ao clima (Arbuthnott e Brigham, 2007), à perturbação antrópica (Mendes et al, 2014) e fontes de alimento. Estima-se que um morcego 
insetívoro de porte mediano (Myotis myotis) tenha uma área de vida de $15 \mathrm{~km}^{2} \mathrm{com}$ a

96 área núcleo variando de 2 a 6 km² $^{2}$ (Drescher, 2004). No entanto em uma área conservada e em pequena escala não se tem informação sobre a resposta destes animais

98 à configuração da paisagem.

Uma vez que morcegos insetívoros são considerados bons indicadores da saúde

100 do ecossistema, e considerando que estes animais influenciam muito a diversidade de mamíferos do Cerrado, faz-se necessário um incremento na amostragem destas espécies por métodos que possam substituir o viés de captura da rede de neblina. Assim, este trabalho teve como objetivo avaliar a atividade de morcegos insetívoros ao longo da noite e verificar se as características paisagem influenciam esta atividade.

Especificamente foram testadas as seguintes hipóteses e predições:

1) A atividade não variará ao longo da noite dado que, a atividade de insetos está correlacionada com a temperatura e a amplitude térmica noturna no Cerrado é mais baixa do que em ambientes temperados, e que o recurso alimentar dos morcegos insetívoros é facilmente renovado durante a noite, existirá atividade destes morcegos durante toda a noite. Assim, espera-se que as medidas da atividade dos morcegos, por meio da bioacústica, reflitam essas mudanças.

2) A atividade de morcegos insetívoros será a mesma entre pontos amostrais próximos de mesma fitofisionomia. Espera-se que, devido à pequena distância entre os pontos amostrais e da grande capacidade de deslocamento dos morcegos, independente das métricas de paisagem, a atividade seja semelhante em todos os pontos, uma vez que o padrão geral da vegetação seja o mesmo (cerrado stricto sensu).

\section{MATERIAIS E MÉTODOS}

Área de estudo

O trabalho foi desenvolvido em uma área de proteção integral, o Parque

122 Nacional de Brasília (PNB) (figura 1). Possui área de 42.389,01 hectares de área de Cerrado (MMA, 2007). Situado dentro do domínio do Cerrado, o PNB é caracterizado

124 por uma grande heterogeneidade de hábitats expressa na forma de diferentes 
fitofisionomias que variam desde formações campestres, rupestres, savânicas e até

126 florestais, de acordo com a altura do dossel (MMA, 2007). Outra característica marcante da região é o clima, segundo a classificação de Köppen, do tipo Aw, com duas estações

128 bem marcadas, sendo o inverno seco e frio, de abril a setembro, e o verão quente e chuvoso, de outubro a março. A precipitação média anual fica em torno de $1500 \mathrm{~mm}$,

130 concentrada nos meses de dezembro e janeiro (MMA, 2007). Devido à localização estratégica do Parque Nacional de Brasília, no ano de 2012, a rede ComCerrado instalou

132 um módulo de pesquisas no parque com base no protocolo do Programa de Pesquisa em Biodiversidade - PPBio, com o intuito de padronizar as técnicas de coleta de dados

134 biológicos no Cerrado.

O módulo RAPELD (RAP - Rapid Assessment Program e PELD - Programas

136 Ecológicos de Longa-Duração) que inicialmente fora desenvolvido para estudos na Amazônia, sofreu algumas modificações para se adequar ao ambiente de Cerrado, uma

138 vez que, neste bioma, a heterogeneidade ambiental é estruturada horizontalmente. $\mathrm{O}$ módulo do PNB então consiste em duas trilhas principais paralelas de $5 \mathrm{~km}$ com $1 \mathrm{~km}$ de

140 distância entre elas. Nas trilhas principais foram marcadas parcelas de $250 \mathrm{~m}$ x 40m a cada $1 \mathrm{~km}$. Em cada uma das 10 parcelas (trilhas norte e sul), foi instalado um gravador

142 de ultrassom para registrar a atividade de morcegos.

\section{Atividade de Morcegos}

144 Para analisar a atividade dos morcegos insetívoros, em cada parcela foi instalado um gravador Song Meter SM2BAT+ com um microfone omnidirecional SMX-US, a

146 pelo menos 3 metros de altura, tomando cuidado para que o microfone não ficasse direcionado para nenhum obstáculo (ex: folhas, troncos de árvores etc.). Os

148 equipamentos foram configurados para gravar com uma taxa de amostragem de 384 kHz. As gravações eram iniciadas por voltas das 18 e cessavam por volta das $6 \mathrm{~h}$. Mais

150 especificamente 30 minutos antes do pôr do sol, com sequências de 5 minutos de gravação e intervalos de 1 minuto entre as sequências. Assim, a cada noite e em cada

152 ponto eram totalizados 145 arquivos de gravações de 5 minutos. Cada ponto foi amostrado duas vezes na mesma estação (seca), em noites de lua nova, para evitar a

154 fobia lunar (Saldaña-Vázquez e Munguía-Rosas, 2013). Em situações de interrupção acidental das gravações durante a noite, o gravador era recolocado no mesmo ponto e a 
156 amostragem era realizada novamente na noite seguinte. Além de gravarem sons, os equipamentos registravam a temperatura ambiente quando se iniciava um novo arquivo 158 de som.

O programa Kaleidoscope Pro versão 3.1.8 (Wildlife Acoustics) foi utilizado

160 para a análise das gravações, sendo que os arquivos originais de 5 minutos foram divididos em arquivos de cinco segundos para melhor visualização. Os chamados foram

162 visualizados no programa BatSound - Sound Analysis, versão 4.2.1 (Petterson Eletronik AB). O espectrograma foi feito na janela Hanning (tamanho 1024) com a resolução de

164 frequência de $525 \mathrm{kHz}$ e 2,7ms o tempo entre os FFTs, sem sobreposição. Todos os 142100 arquivos foram visualmente analisados.

166 A atividade foi medida pela quantidade de passes por hora (passe/hora). Foi considerado um passe de morcego três ou mais pulsos em fase de busca. Um passe era

168 separado do outro sempre que a distância entre os pulsos fosse superior a três vezes o intervalo entre os pulsos. Os arquivos que continham passes de morcegos foram

170 analisados no Kaleidoscope Pro versão 3.1.8 (Wildlife Acoustics) para a identificação automática dos morcegos. Apesar das incertezas nas identificações de espécies

172 automáticas, é possível confiar nas medições das frequências detectadas (Slough et al., 2014). Portanto as espécies foram categorizadas em grupos funcionais de acordo com o

174 ambiente de forrageio (Denzinger e Schnitzler, 2013; Schnitzler e Kalko, 2001): forrageadores de ambiente aberto (frequência do chamado inferior a $30 \mathrm{kHz}$ ),

176 forrageadores de ambiente fechado (frequência do chamado acima de $60 \mathrm{kHz}$ ) e forrageadores de ambiente de borda (frequência do chamado entre 30 e $60 \mathrm{kHz}$ ).

178 Preditores de paisagem

Usando o QGIS 2.18 e o programa R (pacote raster, Hijmans e Van Etten, 2012),

180 foi criado uma faixa de 450 metros no entorno de cada ponto, tendo-se como base uma imagem de satélite LandSat 8 (sensor OLI) com resolução de 30x30 metros. Para

182 caracterizar a heterogeneidade espacial, foram calculados dois índices: (i) índice vegetação por diferença normalizada (NDVI), calculado a partir da diferença entre as

184 reflectâncias das bandas do infravermelho próximo e vermelho visível, dividido pela soma destas. $\mathrm{O}$ índice varia entre 1 e -1, sendo que quanto mais próximo de 1 maior é a 186 presença de biomassa verde. E o (ii) índice de diversidade de paisagem de Simpson (1- 
D) (Lande, 1996), calculado a partir de uma imagem classificada por com Pinto et al.

188 (2009). Um mapa dos corpos d'água da área foi feito utilizando o programa Google Earth para medir a sua menor distância do ponto de coleta. Os corpos d'água mais

190 próximos dos pontos de coleta eram cursos d'água associados a matas de galeria.

\section{Análises estatísticas}

Os dados foram adequados a um modelo linear binomial negativo misto (pacote glmmADMB, Bolker et al., 2012), devido ao excesso de zeros nas amostras. Como

194 variável resposta, utilizou-se o número de passes, e como variável preditora, a quantidade de horas após o pôr-do-sol, uma vez que a variável temperatura estava muito correlacionada com a variável hora $(\mathrm{r}=0,63)$. Os pontos foram utilizados como variável aleatória para controlar a identidade dos mesmos.

Para verificar quais características da paisagem ao redor dos pontos melhor explicam a variação da atividade ao longo da noite, foi feito um modelo linear

200 generalizado (GLM), com distribuição Gaussiana, tendo como variáveis respostas os passes, a distância até o corpo d'água mais próximo, a quantidade de biomassa verde em um buffer de 450 metros, o índice de heterogeneidade de Simpson e a temperatura média do ponto. Nenhuma das variáveis explanatórias estavam correlacionadas.

Utilizando o critério de informação de Akaike (AIC), manualmente, eliminou-se a variável menos significativa $(\mathrm{p}>0.05)$. A variável foi mantida no modelo sempre que, ao retirá-la, o valor do AIC era menor que quando estava presente, melhorando assim o ajuste do mesmo. utilizados para verificar se a média da frequência variaria ou não ao longo da noite. Essa avaliação foi feita por meio de um teste de Kruskal-Wallis. 


\section{RESULTADOS}

1) Atividade de morcegos insetívoros registradas ao longo da noite no módulo PPBio

214 instalado no Parque Nacional de Brasília.

Em 242 horas de gravação foram contabilizados 5024 passes de morcegos

216 (Tabela 3).

Na identificação automática do programa Kaleidoscope PRO foram

218 identificados 1038 passes de morcegos, sendo 775 chamados incluídos no grupo dos forrageadores de borda e 263 no grupo dos forrageadores de área aberta. Foram

220 identificadas 20 espécies pertencentes a cinco famílias: Vespertilionidae (8 espécies), Molossidae (6 espécies), Emballonuridae (4 espécies), Mormoopidae (1 espécie),

222 Noctilionidae (1 espécie) (Tabela 1). São elas Diclidurus albus (14), Epitesicus furinalis (526), Eptesicus fuscus (5), Eumops glaucinus (59), Eumops perotis (29), Lasiurus

224 blossevili (78), Lasiurus cinereus (153), Lasiurus ega (8), Molossus molossus (6), Molossus rufus (1), Molossops temminckii (3), Myotis nigricans (57), Myotis riparius

226 (20), Noctilio leporinus (14), Nyctinomops laticaudatus (3), Peropteryx kappleri (37), Peropteryx macrotis (16), Pteronotus gymnotus (5), Rhogeessa io (2) e Saccopteryx

228 leptura (2). As espécies mais comumente registradas foram Epitesicus furinalis (559) e Lasiurus cinereus, (175), da família Vespertilionidae. Esses registros representam 63\%

230 do total de registros identificados automaticamente.

De forma geral, a atividade de morcegos apresenta um pico logo após o pôr do

232 sol, seguido de um declínio progressivo (tabela 4) e, no meio da madrugada (por volta de 2 horas da manhã), apresenta um leve pico que torna a decair, porém não cessou

234 antes do fim das gravações (figura 2).

O pico médio de frequência emitido por morcegos insetívoros varia entre as

236 horas da noite (Kruskal-Wallis $\mathrm{H}=233,69$; $\mathrm{p}<0,05)$. É possível observar uma mudança na frequência a partir da sexta hora após o pôr do sol (figura 3). Ao dividir as

238 frequências em dois grupos de hora (antes da meia noite e depois da meia noite) vê-se que as frequências nas primeiras horas após o pôr-do-sol são mais altas e com uma 
variação pequena ( $M=40,12 \pm 10,21 \mathrm{kHz})$. No segundo grupo, após a meia noite, a frequência é em média mais baixa $(M=31,87 \pm 13,45 \mathrm{kHz})$.

O padrão de atividade ao longo da noite mostrou-se diferente entre os pontos do módulo (figuras 4 e 5). Ou seja, os morcegos insetívoros apresentam picos de atividade

244 em horários diferentes ao longo da noite, dependendo do ponto. A abundância de passes de morcegos também é diferente entre os pontos (TRV $-\mathrm{G}=9,56 ; \mathrm{p}<0,05$ ). No entanto, um dos pontos de amostragem, o ponto 500N (figura 4a), concentrou cerca de $40 \%$ da atividade total observada. Este fato poderia ter enviesado as análises. Ao retirar esse ponto de amostragem das análises o padrão de atividade de morcegos ao longo da noite e a abundância entre os pontos permanece diferente (TRV $-\mathrm{G}=9,02 ; \mathrm{p}<0,05$ ), portanto 250 este ponto foi mantido.

A frequência média emitida por morcegos em cada ponto é diferente (Kruskal-

252 Wallis $\mathrm{H}=305,06 ; \mathrm{p}<0,05)$, indica uma composição diferente da comunidade entre os pontos.

254 2) Atividade de morcegos insetívoros entre os pontos amostrais do módulo PPBio instalado no Parque Nacional de Brasília.

256 Dentre as espécies identificadas não foram identificados nenhum chamado de forrageadores de ambiente fechado (FAF). O grupo funcional dos forrageadores de 258 ambiente de borda (FAB) foi mais rico e abundante que o grupo dos forrageadores de ambiente aberto (FAA). No entanto entre os pontos de amostragem este padrão não foi

260 o mesmo. O grupo FAB só foi mais rico em quatro locais amostrados (500N, 2500S, $4500 \mathrm{~N}$ e $4500 \mathrm{~S}$ ) (figura 5).

O número de passes foi melhor explicado pela distância ao corpo d'água mais próximo e pelo volume da biomassa, esta relação foi positiva para os dois parâmetros

264 (Tabela 2). Ou seja, quanto mais longe de um corpo d'água maior é a quantidade de passes na região $(t=3,092 ; \mathrm{p}<0,05)$. O índice de vegetação por diferença normalizada -

266 NDVI, também apresenta uma relação positiva com atividade, sendo observada maior atividade de morcegos insetívoros em pontos onde a biomassa é maior $(\mathrm{t}=2,568$; $\mathrm{p}<0,05)$. A variável temperatura foi retirada do modelo $\left(\mathrm{AIC}^{1}=154,7\right)$. Com a retirada 
do índice de diversidade de Simpson (Div.450) melhora o ajuste do modelo (AIC ${ }^{3}=$

270 153,8). Os valores das métricas de paisagem utilizados neste modelo estão na tabela 3.

\section{DISCUSSÃO}

272 1) 1) Atividade de morcegos insetívoros registradas ao longo da noite no módulo PPBio instalado no Parque Nacional de Brasília.

274 O padrão de atividade geral ao longo da noite apresenta um pico nas primeiras horas após o pôr-do-sol e decresce com o passar da noite, apresentando outro leve pico

276 por volta das 2 horas da manhã (figura 2). Portanto, a primeira hipótese foi rejeitada. Morcegos insetívoros não utilizam a noite inteira igualmente. E a atividade de morcegos

278 diminui com o passar da noite. Devido à forte correlação entre a variável hora e a variável temperatura é possível inferir que a atividade de morcegos é menor em horários

mais frios. É conhecido uma associação positiva entre a atividade de insetos e a temperatura (Arbuthnott e Brigham, 2007). Assim, mesmo com a menor amplitude

282 térmica no Cerrado, a temperatura influencia, mesmo que indiretamente, a atividade de morcegos insetívoros.

Apesar de existir atividade durante a noite inteira os morcegos apresentam preferência de horários. O maior pico de atividade sendo nas primeiras horas da noite

286 provavelmente acontece como resultado de um longo período de jejum dentro do abrigo, com um decréscimo que pode corresponder a um retorno ao abrigo durante a noite (Hayes, 1997; Kunz, 1973). O pico inicial de atividade nas primeiras horas da noite é um padrão conhecido para outras áreas e ambientes. Por exemplo, Fenton e

290 Thomas (1980) constataram, em uma savana africana, que morcegos insetívoros da família Vespertilionidae e Molossidae têm o pico de atividade entre 18h e 19h, ou seja,

292 no início da noite, e se mantêm esporadicamente ativos até meia noite. O padrão bimodal de atividade, com um pico de atividade no início da noite e um segundo pouco

294 antes do amanhecer foi encontrado em diferentes ambientes: uma floresta temperada (Hayes, 1997), pradaria (Kunz, 1973), savana africana (Meyer et al., 2004) e floresta tropical (Tasmânia) (Taylor e O’Neill, 1988).

No entanto, dois pontos não apresentaram este padrão de pico de atividade nas primeiras horas da noite: 1500 sul e o 4500 norte (figura 4, itens 1500 sul e 4500 norte). 
O ponto 1500 sul é o ponto com menor volume de biomassa verde dentre os pontos e o

300 ponto 4500 norte apresenta a temperatura média mais baixa dentre os pontos amostrados, cerca de $6^{\circ} \mathrm{C}$ abaixo da média dos pontos. Estes dois fatores estão

302 correlacionados com a presença de insetos (Bale, 1991; Pettorelli et al., 2011), devido a isso estes pontos são menos atrativos para forrageio. Este padrão de pico de atividade

304 tardio na noite foi observado para as espécies Myotis lucifugus, Myotis keenii, Lasionycteris noctivagans, Eptesicus fuscus, Lasiurus borealis, e Lasiurus cinereus

306 (Kunz, 1973).

É possível observar uma partição temporal da noite a partir da média do pico de 308 frequência dos chamados. Na primeira metade da noite os chamados apresentam uma frequência mais alta que na segunda metade. Em média, a faixa de frequência do início

310 da noite é mais alta, indicando um maior uso desse período por morcegos menores (Jakobsen et al., 2013). Morcegos pequenos emitem sons de maior frequência (Patterson

312 et al., 2003). Por tanto é possível concluir que morcegos menores utilizam as primeiras horas da noite, ao passo que a segunda metade da noite é utilizada por morcegos maiores

314 e menores (figura 3). A presença de morcegos pequenos ao longo de toda a noite por ser justificada pelo requerimento energético maior de animais menores (Pough et al, 2008).

316 E para coexistir, animais que utilizam o mesmo recurso no mesmo habitat precisam se diferenciar em alguma dimensão do nicho, ou uma das espécies será excluída. As espécies

318 de morcegos insetívoros que utilizam recursos similares variam a exploração deste no tempo, apresentando picos de frequência diferentes, porém próximos (Adams e Thibault,

320 2006; Emrich et al., 2014). Grupos de morcegos insetívoros com estratégias de forrageamento similares ocorrem no mesmo horário (Fenton e Thomas, 1980). Isso

322 provavelmente ocorre devido a disponibilidade de insetos, que variam sua abundancia durante a noite (Beck e Linsenmair, 2006).

324 2) Atividade de morcegos insetívoros entre os pontos amostrais do módulo PPBio instalado no Parque Nacional de Brasília.

A abundância de registros de atividade de morcegos insetívoros é diferente entre os pontos (figura 4), refutando a segunda hipótese testada neste trabalho. Apesar de

328 todos os pontos de coleta terem sido em áreas predominantemente de cerrado stricto 
sensu e estes animais terem a capacidade de alcançar todos os pontos em uma só noite, a 330 atividade está distribuída de maneira heterogênea no espaço.

Constatou-se que, quanto mais longe de um corpo d'água, maior era a atividade 332 dos morcegos. Diferente do observado por Brooks e Ford (2005) e Menzel et al. (2005) em zona subtropical e Almeida et al. (2007) na Mata Atlântica (zona tropical), onde

334 encontraram uma forte correlação entre a atividade de morcegos insetívoros e a proximidade de corpos d'água. Esses autores argumentam que os morcegos utilizam 336 essas áreas para beber água e devido a maior disponibilidade de insetos. No entanto, o Cerrado se difere destes locais devido a uma particularidade das suas formações

338 florestais. Elas sempre aparecem ao redor dos corpos d'água. São chamadas de mata de galeria. Essas matas são relativamente densas, o que impede a navegação eficiente de

340 morcegos insetívoros de área aberta (FAA). O eco do ambiente fechado da mata confunde o sonar destes morcegos que por sua vez ficam incapacitados de perceber o

342 ambiente. Alguns morcegos, os forrageadores de área de borda (FAB), produzem pulsos de ecolocalização para ambiente de borda onde o eco do ambiente é intermediário.

344 Porém Bader et al. (2015) observaram que algumas espécies desta guilda são aptas a utilizar habitats abertos, como os pastos.

346 O volume de biomassa verde apresentou uma associação positiva com a atividade de morcegos insetívoros. A guilda dos FAB apresenta algumas adaptações no

348 seu pulso de ecolocalização que são também úteis para forragear em área de Cerrado stricto sensu, pois este é um ambiente nem muito aberto e nem muito fechado. Esta

350 fitofisionomia possui uma grande abundância de insetos (Diniz et al., 1999; Pinheiro et al., 2002). Áreas com um volume de biomassa verde mais alto tem maior abundância de insetos (Pettorelli et al., 2011). A forte correlação entre a atividade de insetos noturnos e a atividade de morcegos insetívoros é amplamente relatada (Hagen e Sabo, 2014; Kunz,

354 1973; Mendes et al., 2016; Meyer et al., 2004; Rydell et al., 1996). Porém, inexistem dados suficientes sobre a comunidade de insetos nos respectivos pontos de coleta para 356 explicar detalhadamente o padrão de uso do habitat por morcegos.

Observou-se que a riqueza de espécies entre os pontos de coleta foi diferente.

358 Apesar de a atividade de morcegos estar mais associada à maior distância da água, a riqueza de espécies do grupo FAB (o grupo mais ativo) é maior em pontos mais 
360 próximos de corpos d'água (com exceção do ponto 500 norte). Essa maior riqueza pode significar que os animais vão para locais próximos da água para beber água, mas para

362 forragear eles preferem área de cerrado stricto sensu com maior volume de biomassa verde.

364 A espécie mais abundante na área de estudo foi Eptesicus furinalis, concentrando $51 \%$ do total de passes identificados automaticamente pelo Kaleidoscope

366 PRO. Em inventários realizados em área de Cerrado stricto sensu esta espécie é bem amostrada (Gregorin et al., 2011; Loureiro e Gregorin, 2015), porém, como esses

368 inventários são realizados com redes de neblinas a abundância não é muito significativa quando comparada à de morcegos Phyllostomidae não insetívoros capturados. As

370 famílias mais abundantes foram Vespertilionidae e Molossidae concentrando $63 \%$ do total de passes identificados. Dentre os morcegos insetívoros, espécies pertencentes a

372 essas famílias são as que mais aparecem em inventários realizados no Cerrado (Aguiar and Antonini, 2008; Ferreira et al., 2010; Gregorin et al., 2011; Loureiro e Gregorin,

374 2015; Zortéa e Alho, 2008). Essas famílias forrageiam em áreas diferentes e emitem pulsos de ecolocalização de formas diferentes, o que indica que não competem por

376 alimento. Com exceção de Molossops temminckii, os molossídeos identificados são animais que vocalizam abaixo de $30 \mathrm{kHz}$, indicando que esses animais são maiores

378 (Jakobsen et al., 2013) portanto, se alimentam de uma maior variedade de insetos, incluindo insetos maiores. Assim não competem com os vespertilionideos, que são

380 menores, emitem sinais com frequências mais altas, ou seja, comem insetos menores, ocupando então, outro nicho.

382 Conclusão

Morcegos insetívoros estão ativos a noite inteira, mas apresentam dois picos de

384 atividade durante a noite, sendo o mais intenso logo após o pôr-do-sol e o segundo, mais discreto, por volta de duas horas da manhã. No entanto, o padrão de atividade temporal

386 de morcegos insetívoros no Cerrado é diferente entre pontos que os animais podem alcançar em uma noite, mesmo em uma área bem conservada. Isso indica que o contexto

388 da paisagem é importante na escolha do local de forrageio, mesmo em pequena escala. A proximidade da mata diminui a atividade de morcegos insetívoros que preferem forragear em ambiente de Cerrado stricto sensu, porém apresentam preferência por 
ambiente de Cerrado com uma maior biomassa. Mas a riqueza está mais associada a proximidade da água. Indicando que os animais podem utilizar essas áreas para beber água, mas não para forrageamento.

Trabalhos futuros onde mais pontos de coleta sejam amostrados, e que incluam a captura de insetos durante a noite para correlacionar a flutuação da riqueza e abundância de insetos com a flutuação na atividade de morcegos, são necessários para melhor elucidar o padrão de atividade de morcegos insetívoros no Cerrado.

\section{REFERENCIAS}

Adams, R. A. and K. M. Thibault, K. M. 2006. Temporal resource partitioning by bats at water holes. Journal of Zoology. 270(3): 466-472.

Aguiar, L. M. S. and Y. Antonini. 2008. Diet of two sympatric insectivores bats 402 (Chiroptera: Vespertilionidae) in the Cerrado of Central Brazil. Revista Brasileira de Zoologia, 25(1): 28-31.

Aguiar, L.M.S. and J. Marinho-Filho, 2004. Activity patterns of nine phyllostomid bat species in a fragment of the Atlantic Forest in southeastern Brazil. 406 Revista Brasileira de Zoologia, 21(2): 385-390.

Almeida M. H., A. D, Ditchifield, R. S. Tokumaru. 2007. Bats activity and 408 habitat preference in the urban area of Grande Vitória, ES, Brazil. Zoociências. 9:1318. [In Portuguese].

410 Arbuthnott, D. and R. M. Brigham. 2007. The influence of a local temperature inversion on the foraging behaviour of big brown bats, Eptesicus fuscus. Acta

412 Chiropterologica, 9(1): 193-201.

Bader, E., K. Jung, E. K. V. Kalko, R. A. Page, R. Rodriguez and T. Sattler. 414 2015. Mobility explains the response of aerial insectivorous bats to anthropogenic habitat change in the Neotropics. Biological Conservation, 186: 97-106. 
Beck, J. and E. Kalko. 2006. Feasibility of light-trapping in community research on moths: Attraction radius of light, completeness of samples, nightly flight times and seasonality of Southeast-Asian hawkmoths (Lepidoptera: Sphingidae). Journal of Research on the Lepidoptera, 39: 18-37.

Bernard, E. 2002. Diet, activity and reproduction of bats species (Mammalia, Chiroptera) in Central Amazonia, Brazil. Revista Brasileira de Zoologia, 19(1): 173188.

Bernard E., M. B. Fenton. 2003. Bat mobility and roosts in a fragmented 426 landscape in central Amazonia, Brazil. Biotropica. 35: 262-277.

Bolker, B., H. Skaug, A. Magnusson, A. Nielsen. 2012. Getting started with the 428 glmmADMB package. R package versiom 2.0-8, p.12.

Borlaug, N.E. 2002. Feeding a world of 10 billion people: the miracle ahead. Pp. $43029-59$, in global warming and other eco-myths (R. Bailey, ed). Roseville, California: Competitive Enterprise Institute, 1-320p

Broders, H.G., G. M. Quinn and G. J. Forbes. 2003. Species status, and the spatial and temporal patterns of activity of bats in southwest Nova Scotia, Canada. 434 Northeastern Naturalist, 10(4): 383-398.

Brooks, R.T. and W. M. Ford. 2005. Bat activity in a forest landscape of Central 436 Massachusetts. Northeastern Naturalist, 12(4): 447-462.

Carothers, J.H. and F. M. Jaksić. 1984. Time as a niche difference: The role of 438 interference competition. Oikos, 42(3): 403-406.

Cavalcanti, R. B. and C. A. Joly, C.A. 2002. Biodiversity and conservation 440 priorities in the Cerrado Region. Pp 351-368, in The Cerrados of Brazil: Ecology and Natural History of a Neotropical Savanna. (P. S. Oliveira and R. J. Marquis, eds.) New 442 York: Columbia University Press, 398 pp.

Denzinger, A. and H. U. Schnitzler., 2013. Bat guilds, a concept to classify the 444 highly diverse foraging and echolocation behaviors of microchiropteran bats. Frontiers in Physiology, 1-16. 
Diniz, I. R., H. C. Morais, A. M. F. Botelho, F. Venturoli, B. C. Cabral. 1999. Lepidopteran caterpillar fauna on lactiferous host plants in the Central Brazilian 448 Cerrado. Revista Brasileira de Biologia, 59(4).

Drescher, C. 2004. Radiotracking of Myotis myotis (Chiroptera, 450 Vespertilionidae) in South Tyrol and implications for its conservation. Mammalia, 68(4): 395.

Emrich, M. A., E. L. Clare, W. O. C. Symondson, S. E. Koenig, M. B. Fenton. 2014. Resource partitioning by insectivorous bats in Jamaica. Molecular Ecology, 454 23(15): 3648-3656.

Erkert, H. G., 2000. Bats - Flying nocturnal mammals. Pp. 253-272. in Activity 456 patterns in small mammals (S. Halle, N.C. Stenseth eds). Springer Berlin Heidelberg, $322 \mathrm{p}$.

Fenton, M.B. and D. W. Thomas. 1980. Dry-season overlap in activity patterns, habitat use, and prey selection by sympatric African insectivorous bats. Biotropica, 460 12(2): 81-90.

Ferreira, C. M. M., E. Fischer, and A. Pulchério-Leite. 2010. Fauna of bats in 462 urban remnants of Cerrado in Campo Grande, Mato Grosso do Sul . Biota Neotropica, 10(3): 155-160. [In Portuguese].

Gregorin, R., E. Gonçalves and C. C. Aires, and A. P. Carmignotto. 2011. Bats (Mammalia: Chiroptera) from the Serra Geral do Tocantins Ecological Station: specific 466 composition and taxonomic considerations. Biota Neotropica, 11(1): 299-311. [In Portuguese]

Griffin, D. R. 2002. The Past and Future History of Bat Detectors. Pp. 6-9, in Bat Echolocation Research: Tools, Techniques and Analysis (R. M. Brigham, E. K. V. 470 Kalko, G. Jones, S. Parsons, H. J. G. A. Limpens). Bat Conservation International, Austin, Texas, USA, vii + 174 pp. 

activity in riparian habitats over an elevational gradient. Canadian Journal of Zoology, 474 77(1989): 972-977.

Hagen, E.M. and J. L. Sabo. 2014. Temporal variability in insectivorous bat 476 activity along two desert streams with contrasting patterns of prey availability. Journal of Arid Environments, 102: 104-112.

Hayes, J.P., 1997. Temporal Variation in Activity of Bats and the Design of Echolocation-Monitoring Studies. American Society of Mammalogists, 78(2): 514-524.

Hijmans, R.J. and Van Etten, J., 2012. Raster: Geographic analysis and modelling with raster data. , p.R package version 2.0-12.

Jakobsen, L., J. M. Ratcliffe and A. Surlykke. 2013. Convergent acoustic field of view in echolocating bats. Nature, 493(7430): 93-6. noctem: The importance of bats as bioindicators. Endangered Species Research, 8(1-2): 486 93-115.

Jung, K. and E. K. V. Kalko. 2011. Adaptability and vulnerability of high flying 488 Neotropical aerial insectivorous bats to urbanization. Diversity and Distributions, 17(2): $262-274$.

Kalko, E. K. V., C. O. Handley and D. Handley. 1996. Organization, Diversity, and Long-Term Dynamics of a Neotropical Bat Community. Pp. 503-553, in Long-

492 Term Studies of Vertebrate Communities. (M. L. Cody and J. A. Smallwood, eds). Academic Press, 597p.

494

Kunz, T. H., E. B. Torrez, D. Bauer, T. Lobova, T. H. Fleming. 2011. Ecosystem services provided by bats. Annals of the New York Academy of Sciences, 1223(1): 1496 38.

Kunz, T. H. 1973. Resource utilization: temporal and spatial components of bat 498 activity in central Iowa. Journal of Mammalogy, 54(1): 14-32. 
Lande, R. 1996. Statistics and Partitioning of Species Diversity, and Similarity 500 among Multiple Communities. Oikos, 76(1): 1-5.

Loureiro, L.O. and R. Gregorin. 2015. Structure of a Bat Assemblage From a

502 Fragmented Landscape in the State of Minas Gerais, Southeastern Brazil. Mastozoología Neotropical, 22(1): 35-42.

504

Mendes, E. S., C. Fonseca, S. F. Marques, D. Maia, M. J. R. Pereira. 2016. Bat richness and activity in heterogeneous landscapes: guild-specific and scale-dependent?

506 Landscape Ecology, 10: 1-17.

Menzel, J. M., M. A. Menzel, J. C. Kilgo, W. M. Ford, J. W. Edwards. 2005. Bat 508 response to Carolina bays and wetland restoration in the southeastern U.S. coastal plain. Wetlands, 25(3): 542-550.

Meyer, C.F.J., Schwarz, C.J. and Fahr, J., 2004. Activity patterns and habitat preferences of insectivorous bats in a West African forest-savanna mosaic. Journal of

512 Tropical Ecology, 20(July), pp. 397-407.

Ministério do Meio Ambiente (MMA), 2007. Plano de Manejo do Parque

514 Nacional de Brasília (ID 159). pp. 1-5.

Patterson, B. D., M. R. Willing and R. Stevens, R., 2003 Trophic Strategies,

516 Niche Partioning, and Patterns of Ecological Organization. . Pp. 536 - 579, in Bat Ecology. (T. H. Kunz and M. B. Fenton, eds.). Chicago: University of Chicago Press, $518779 \mathrm{p}$.

Pettorelli, N., S. Ryan, T. Mueller, N. Bunnefeld, B. Jedrzejewska, M. Lima and 520 K. Kausrud. 2011. The Normalized Difference Vegetation Index (NDVI): Unforeseen successes in animal ecology. Climate Research 46(1): 15-27.

Pianka, E.R., 1973. The structure of lizard communities. Annu. Rev. Ecol. Syst., 4: 53-74. of insect abundance in the Brazilian cerrado. Austral Ecology, 27: 132-136. 

the cerrado and the types of preserved vegetation formations. Natureza a Conservacao, 528 7(2): 57-71. [In Portuguese]

Presley, S. J., M. R. Willig, I. Castro-Arellano and S. C. Weaver (a). 2009. 530 Effects of habitat conservation on temporal activity patterns of Phyllostomid bats in lowland Amozonian rain forest. Journal of Mammalogy, 90(1): 210-221.

Ramirez-Pulido, J. and M. S. Armella. 1987. Activity patterns of neotropical bats (Chiroptera: Phyllostomidae) in Guerrero, Mexico. The Southwestern Naturalist, 534 32(3): 363-370.

Ribeiro, J. F. and B. M. T. Walter. 2008. The main phytophysiognomies of the 536 Cerrado Biome. Pp 151-212, in Cerrado: ecology and flora vol 1 (S.M. Sano, S.P. Almeida \& J.F. Ribeiro, eds.). Embrapa Cerrados, Planaltina. Ribeiro, J.F. and Walter, 538 B.M.T., 1279 p. [In Portuguese]

Rydell, J., A. Entwistle, P. A. Racey. 2002. Acoustic identification of 540 insectivorous bats (order Chiroptera) of Yucatan, Mexico. Journal of Zoology, 257(1): $27-36$.

Rydell, J., A. Entwistle and P.A. Racey. 1996. Timing of Foraging Flights of Three Species of Bats in Relation to Insect Activity and Predation Risk. Oikos, 76(2): 544243.

Saldaña-Vázquez, R.A. and M. A. Munguía-Rosas. 2013. Lunar phobia in bats 546 and its ecological correlates: A meta-analysis. Mammalian Biology, 78(3): 216-219.

Schnitzler, H. U. and E. K. V. Kalko. 2001. Echolocation by Insect-Eating Bats. 548 BioScience, 51(7): 557.

Slough, B.G., T. S. Jung, and C. L. Lausen. 2014. Acoustic Surveys Reveal 550 Hoary Bat (Lasiurus cinereus) and Long-Legged Myotis (Myotis volans) in Yukon. Society for Northwestern Vertebrate Biology, 95(3): 176-185. 

insectivourous Bats and thier prey in tasmania. Australien Wilflife Research, 55(15): $554533-539$.

Teixeira, T.S.M., D. Dias and M. M. Vale. 2015. New records and a taxonomic 556 review prompts reassessment of Lonchophylla bokermanni, a rare bat endemic to the Brazilian Cerrado. Oryx, 49(1): 71-73. insectivourous Bats and thier prey in tasmania. Australien Wilflife Research, 55(15): $560533-539$.

Zortéa, M. and C. J. R. Alho. 2008. Bat diversity of a Cerrado habitat in central 562 Brazil. Biodiversity and Conservation, 17(4): 791-805.
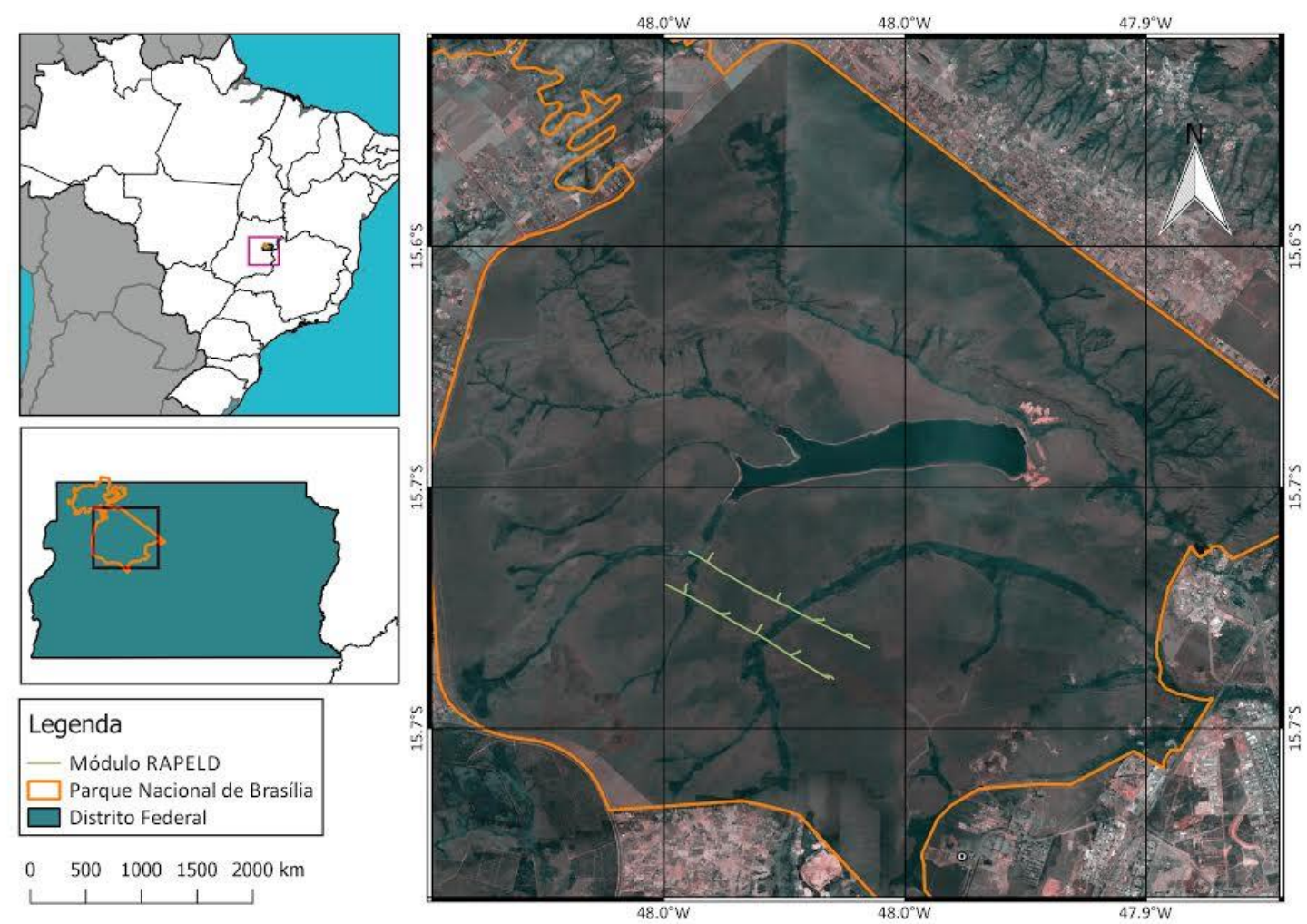

566 Figura 1: Parcelas do módulo PPBio instalado no Parque Nacional de Brasília. 


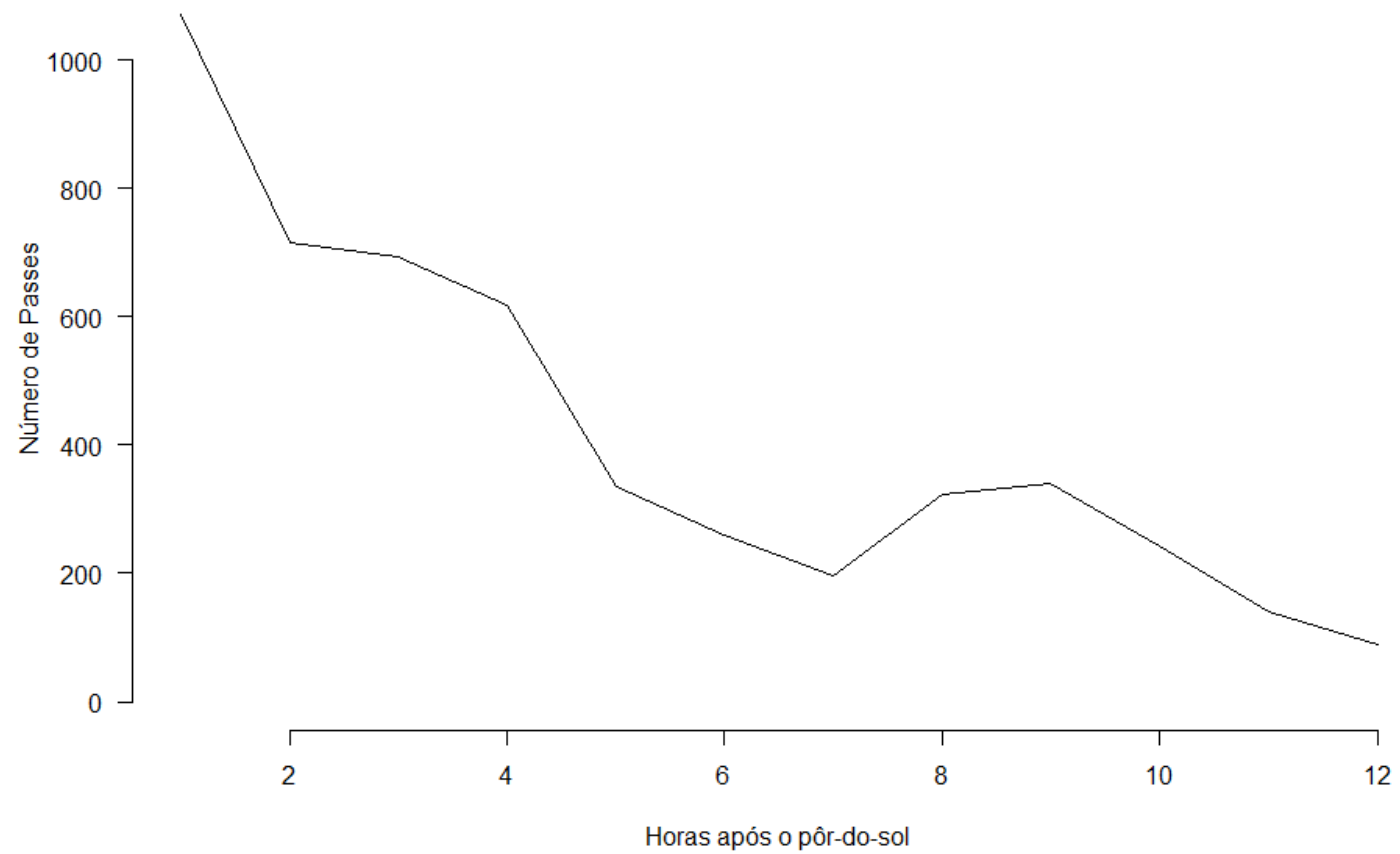

Figura 2: Atividade de morcegos registradas ao longo das noites de amostragem, nos 570 meses de agosto e setembro de 2014, nas parcelas do módulo PPBio instalado no Parque Nacional de Brasília.

572

574

576

578 


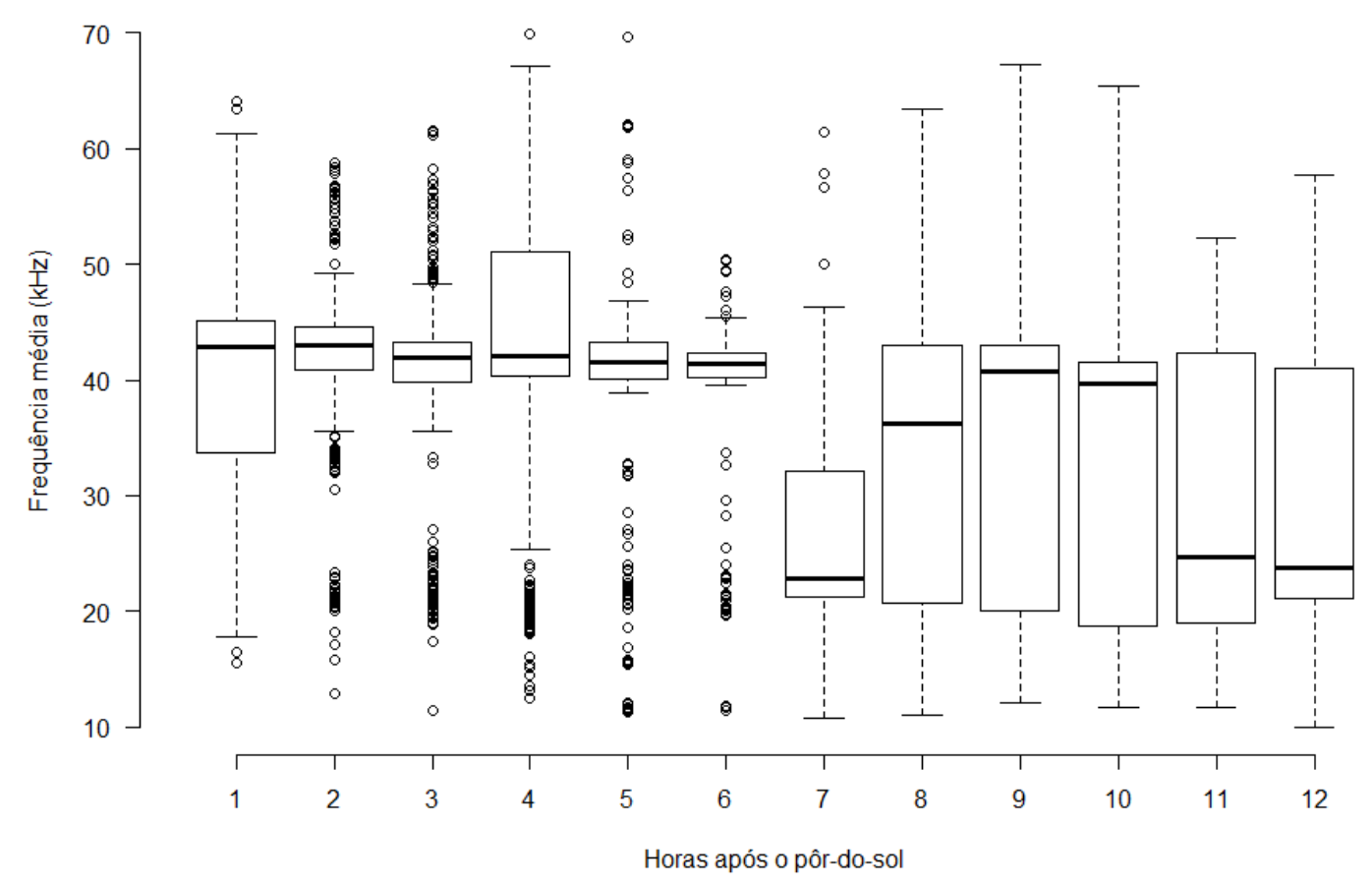

584 Figura 3: Frequência média $(\mathrm{kHz})$ dos chamados de morcegos detectados automaticamente pelo programa Kaleidoscope PRO em relação às horas após o pôr-do586 sol nas noites de amostragem, nos meses de agosto e setembro de 2014, nas parcelas do módulo PPBio instalado no Parque Nacional de Brasília. 


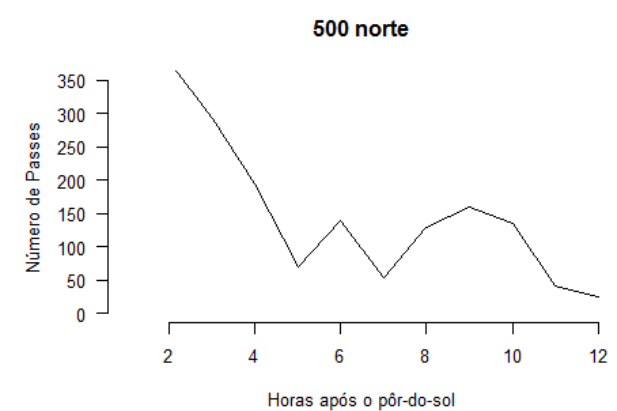

1500 norte

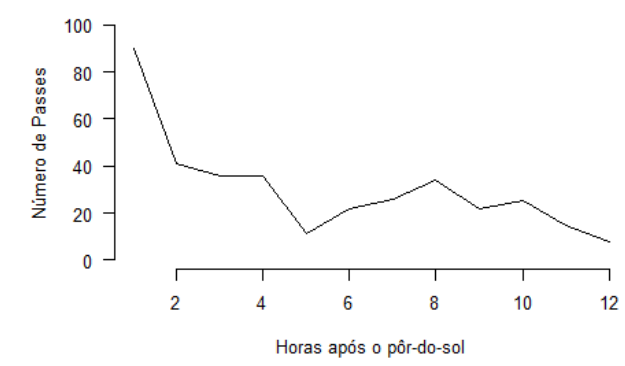

2500 norte

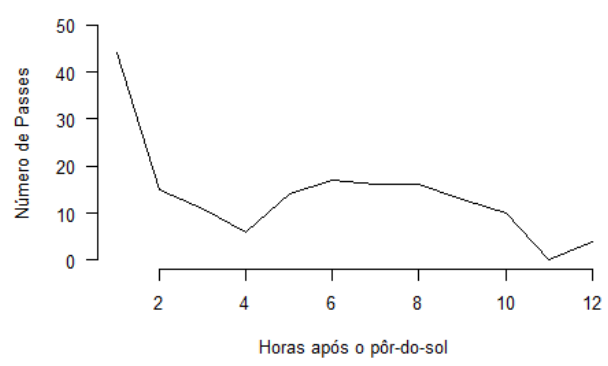

590

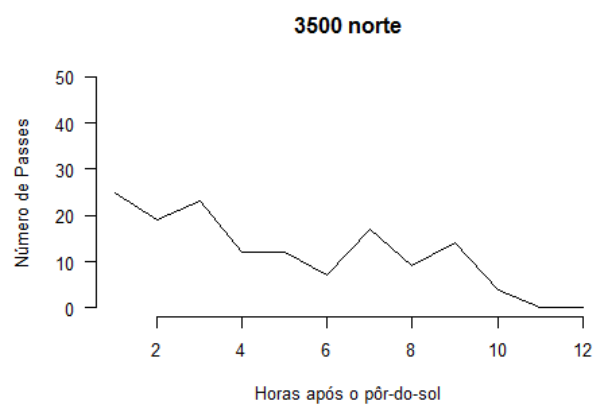

4500 norte

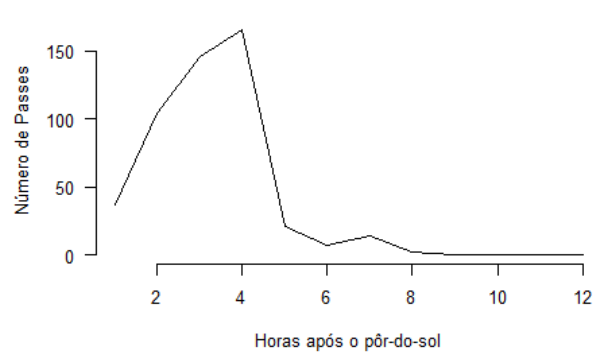

500 sul

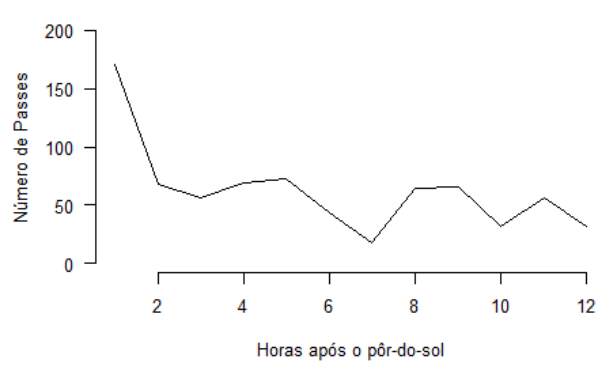

1500 sul

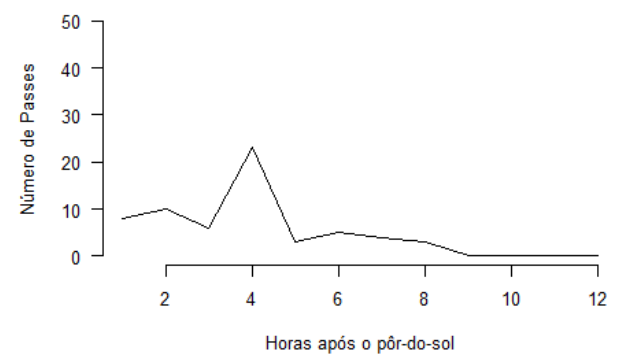

2500 sul

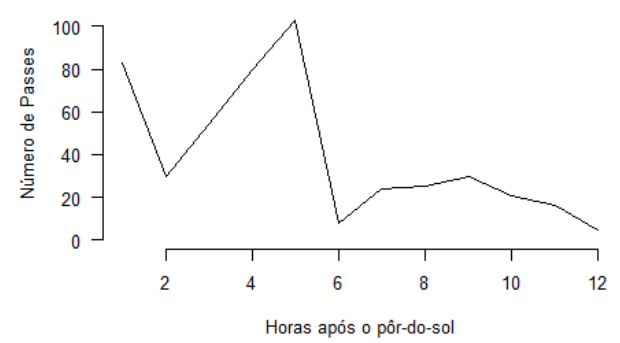

3500 sul

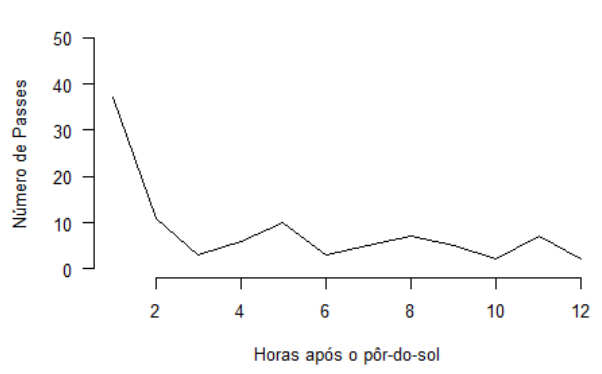

4500 sul

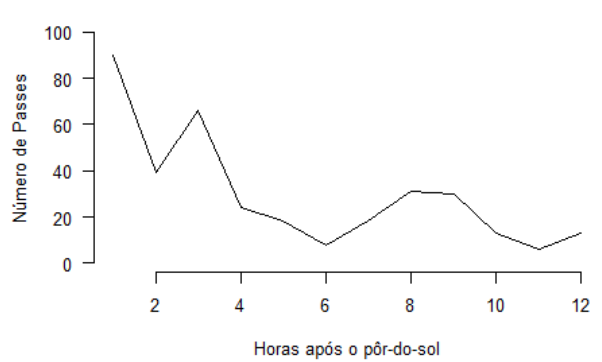

592 Figura 4: Padrão de atividade de morcegos insetívoros nas noites de amostragem, nos meses de agosto e setembro de 2014, nas parcelas do módulo PPBio instalado no Parque 
594 Nacional de Brasília.nos pontos do módulo PPBio instalado no Parque Nacional de Brasília. Os eixos Y é diferente entre os gráficos.

596

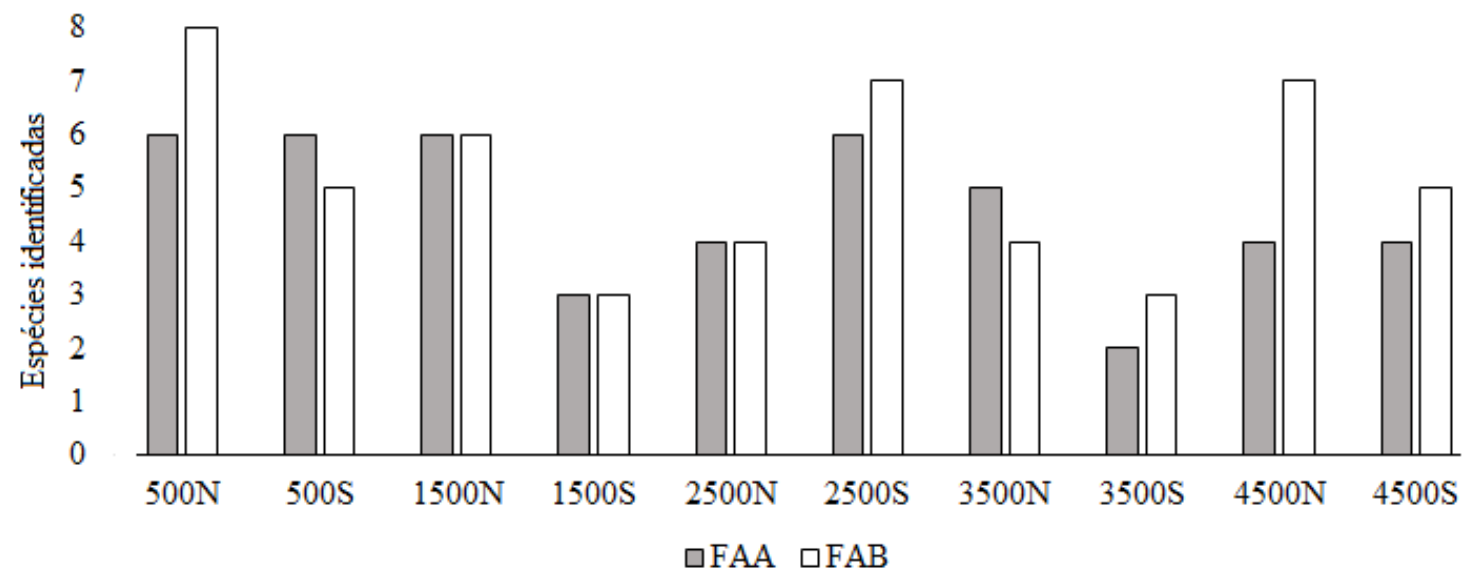

598 Figura 5: Número de espécies identificadas em cada grupo funcional nas parcelas do módulo PPBio instalado no Parque Nacional de Brasília. 
TABELAS

602

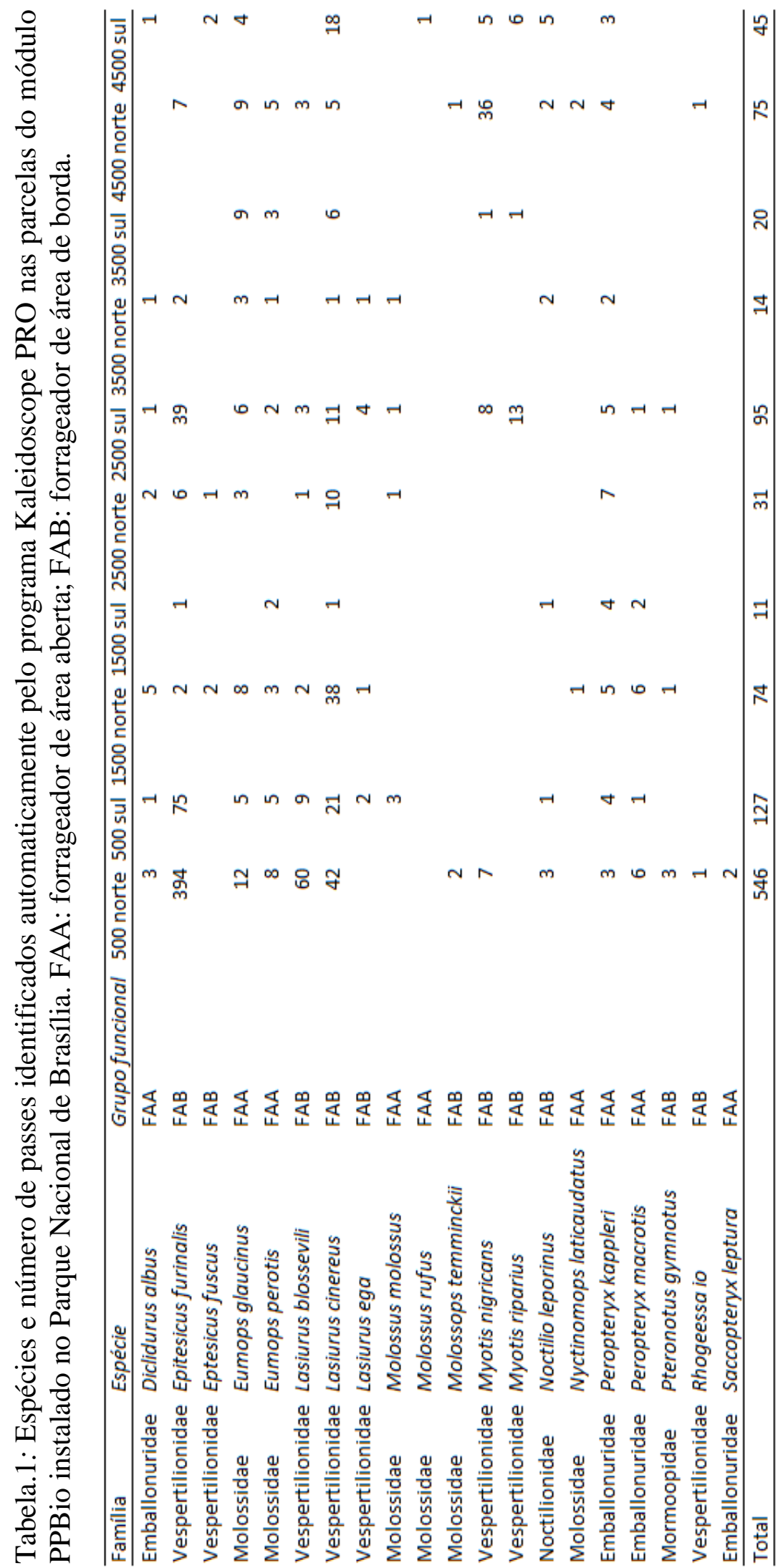


604 Tabela 2: Modelo selecionado que melhor explica a atividade de morcegos insetívoros no módulo PPBio instalado no Parque Nacional de Brasília. NDVI = índice de vegetação por 606 diferença normalizada; dist.agua = distância do corpo d'água mais próximo; Div.450 = índice de diversidade de Simpson (1-D) da paisagem, calculado por um buffer de 450 608 metros.

$\mathrm{M}^{2}: \mathrm{gIm}\left(\right.$ formula $=$ passe $\sim \mathrm{NDVI}+$ Dist.agua + div.450) $\mathrm{AIC}^{3}=153.8$

\begin{tabular}{lccc}
\hline & Estimativa & Valor de t & Valor de $\mathrm{p}$ \\
\hline (intercepto) & 26845.1917 & -2.437 & $0.05060^{*}$ \\
NDVI & 10454.9201 & 2.568 & $0.0425^{* *}$ \\
dist.agua & 0.8615 & 3.092 & $0.0213^{* *}$ \\
\hline & código de significância : $0.05^{\prime * * " ;} ; 0.1^{\prime *}$ & \\
\hline
\end{tabular}


610 Tabela 3: Métricas de paisagem no módulo PPBio instalado no Parque Nacional de Brasília. NDVI = índice de vegetação por diferença normalizada; Diversidade = índice 612 de diversidade de Simpson (1-D).

\begin{tabular}{lllll}
\hline Ponto & NDVI & Temperatura $\left({ }^{\circ} \mathrm{C}\right)$ & Distância da água $(\mathrm{m})$ & Diversidade \\
\hline $500 \mathrm{~N}$ & 0.223337 & 19.80 & 1412 & 0.135098 \\
$500 \mathrm{~S}$ & 0.199182 & 18.95 & 1465 & 0 \\
$1500 \mathrm{~N}$ & 0.20889 & 20.63 & 501 & 0.278097 \\
$1500 \mathrm{~S}$ & 0.181454 & 21.43 & 768 & 0.425612 \\
$2500 \mathrm{~N}$ & 0.204936 & 20.08 & 455 & 0 \\
$2500 \mathrm{~S}$ & 0.230007 & 19.34 & 199 & 0.272942 \\
$3500 \mathrm{~N}$ & 0.203232 & 18.88 & 1277 & 0.617863 \\
$3500 \mathrm{~S}$ & 0.205418 & 17.79 & 834 & 0.246069 \\
$4500 \mathrm{~N}$ & 0.209292 & 12.92 & 292 & 0 \\
$4500 \mathrm{~S}$ & 0.220955 & 17.50 & 60 & 0 \\
\hline
\end{tabular}


Tabela 4. Modelo selecionado que melhor explica a atividade de morcegos insetívoros no 616 módulo PPBio instalado no Parque Nacional de Brasília ao longo da noite.

\begin{tabular}{lllll}
\hline \multicolumn{5}{l}{ Modi: passe Nhora + (hora ponto), familla binomial } \\
& Estimado & Erro padrẵo & z & p \\
\hline (intercepto) & 3,7759 & 0,331 & 11,41 & $2^{-16}$ \\
Hora & $-0,2302$ & 0,0462 & $-4,99$ & $5,9^{-7}$ \\
\hline
\end{tabular}

